This is the peer reviewed version of the following article: Tuscher, L., Helling, C., Wölper, C., Frank, W., Nizovtsev, A.S., Schulz, S.: A General Route to Metal - Substituted Dipnictenes of the Type [L(X)M]2E2. Chemistry - A European Journal 2018, 24, 3241-3250, which has been published in final form at: https://doi.org/10.1002/chem.201705233

WILEY-VCH

\title{
A general route to metal-substituted dipnictenes of the type $[L(X) M]_{2} E_{2}(M=A l, G a ; E=A s, B i ; X=$ halide, amide)
}

\author{
Lars Tuscher, ${ }^{[a]}$ Christoph Helling, ${ }^{[a]}$ Christoph Wölper, ${ }^{[a]}$ Walter Frank, ${ }^{[b]}$ Anton S. Nizovtsev, ${ }^{[c, d, e]}$ and \\ Stephan Schulz ${ }^{*[a]}$
}

\begin{abstract}
Two equivalents of $L G a\left\{L=H C\left[C(M e) N\left(2,6-i \mathrm{Pr}_{2} \mathrm{C}_{6} \mathrm{H}_{3}\right)\right]_{2}\right\}$ react with $\mathrm{PX}_{3}(X=\mathrm{Cl}, \mathrm{Br})$ with insertion into two $\mathrm{P}-\mathrm{X}$ bonds and formation of $[\mathrm{L}(\mathrm{X}) \mathrm{Ga}]_{2} \mathrm{PX}(\mathrm{X}=\mathrm{Cl} 1, \mathrm{Br} 2)$, whereas the analogous reaction with $\mathrm{AsCl}_{3}$ occurred with twofold insertion and subsequent elimination of $\mathrm{LGaCl}_{2}$ and formation of the Ga-substituted diarsene $\left[\mathrm{L}(\mathrm{Cl}) \mathrm{Ga}_{2} \mathrm{As}_{2}(3)\right.$. Analogous findings were observed in the reactions with $\mathrm{Me}_{2} \mathrm{NAsCl}_{2}$, yielding the unsymmetrically-substituted diarsene $[\mathrm{L}(\mathrm{Cl}) \mathrm{Ga}] \mathrm{As}=\mathrm{As}\left[\mathrm{Ga}\left(\mathrm{NMe}_{2}\right) \mathrm{L}\right](4)$. The reaction of $\mathrm{As}\left(\mathrm{NMe}_{2}\right)_{3}$ with $\mathrm{LGa}$ gave $\left[\mathrm{L}\left(\mathrm{Me}_{2} \mathrm{~N}\right) \mathrm{Ga}\right]_{2} \mathrm{As}_{2}(5)$ after heating at $165^{\circ} \mathrm{C}$ for 5 days, while the reaction with $\mathrm{LAl}$ gave $\left[\mathrm{L}\left(\mathrm{Me}_{2} \mathrm{~N}\right) \mathrm{Al}\right]_{2} \mathrm{As}_{2}(6)$ after heating at only $80^{\circ} \mathrm{C}$ for 1 day. Finally, two equivalents of $L G a$ reacted with $\mathrm{Bi}\left(\mathrm{NEt}_{2}\right)_{3}$ to $\left[\mathrm{L}\left(\mathrm{Et}_{2} \mathrm{~N}\right) \mathrm{Ga}_{2} \mathrm{Bi}_{2}(\mathbf{7}) .1\right.$ - $\mathbf{7}$ were characterized by NMR spectroscopy $\left({ }^{1} \mathrm{H},{ }^{13} \mathrm{C},{ }^{31} \mathrm{P}\right)$, elemental analysis and single crystal $\mathrm{X}$-ray diffraction (except 1 and 5 ). The bonding situations in 4,6 and 7 were analyzed by quantum chemical calculations.
\end{abstract}

\section{Introduction}

Monovalent group 13 diyls LM (M = Al, Ga; L = HC[C(Me)N(2,6$\left.\left.\left.i \mathrm{Pr}_{2} \mathrm{C}_{6} \mathrm{H}_{3}\right)\right]_{2}\right\}$ ) containing an $\mathrm{N}, \mathrm{N}$-chelating $\beta$-diketiminate ligand exhibit bifunctional properties due to the presence of an electron lone pair, which render these molecules rather Lewis basic, and a formally vacant $\pi$-orbital, according to which they show a Lewis acidic character. They therefore act as nucleophiles, i.e., in coordination chemistry, but also show electrophilic reactivity, and this unique reactivity has led to several applications in synthetic chemistry, in particular in the activation of small molecules. ${ }^{[1]}$ Despite their structural analogy, the electronic structure of monovalent $\mathrm{LAl}$ and $\mathrm{LGa}$ slightly differs. Both show sp-like

[a] M. Sc. L. Tuscher, B. Sc. C. Helling, Dr. C. Wölper, Prof. Dr. S Schulz

Faculty of Chemistry and Center for Nanolntegration (Cenide), University of Duisburg-Essen, Universitätsstr. 5-7, S07 S03 C30, D45117 Essen, Germany

Fax: (+) 201-183 3830; E-mail: stephan.schulz@uni-due.de https://www.uni-due.de/ak_schulz/index_en.php

[b] Prof. Dr. W. Frank

Institute for Inorganic Chemistry and Structural Chemistry, Heinrich Heine University of Düsseldorf; Universitätsstr. 1, 40225 Düsseldorf, Germany

[c] Dr. A. S. Nizovtsev

Nikolaev Institute of Inorganic Chemistry, Siberian Branch of the

Russian Academy of Sciences, Academician Lavrentiev Avenue 3 , 630090, Novosibirsk, Russian Federation

[d] Novosibirsk State University, Pirogova Street 2, 630090 , Novosibirsk, Russian Federation

[e] School of Chemistry, University of Nottingham, University Park Nottingham NG7 2RD, United Kingdom

Supporting information for this article (experimental details including ${ }^{1} \mathrm{H},{ }^{13} \mathrm{C}$ NMR, IR spectra and computational details) is available on the WWW under http://dx.doi.org/xxx</. hybridized, doubly occupied HOMOs and $\pi^{*}$-like LUMOs localized at the $\mathrm{C}-\mathrm{N}$ unit of the ligand. The empty metal $\mathrm{p}$-orbitals in both compounds are the LUMO+1. Quantum chemical calculations revealed that the singlet-triplet energy gap (Al: $34.3-45.7 \mathrm{kcal} / \mathrm{mol}$; Ga: $51.7-55.5 \mathrm{kcal} / \mathrm{mol}$ ) as well as the HOMO-LUMO separation (Al: $75.76 \mathrm{kcal} / \mathrm{mol}$; Ga $96.24 \mathrm{kcal} / \mathrm{mol}$ ) in LAl is smaller than in LGa. ${ }^{[2]}$ In addition, LAl and LGa display somewhat different chemical reactivity. The chemistry of LAI mainly focused on bond activation reactions, e.g. small molecule activation $\left(\mathrm{P}_{4}, \mathrm{O}_{2}, \mathrm{~S}_{8} \text {, azobenzene, azides }\right)^{[3]}$ as well as $\mathrm{H}-\mathrm{X}(\mathrm{X}=$ $\mathrm{H}, \mathrm{Si}, \mathrm{B}, \mathrm{Al}, \mathrm{C}, \mathrm{N}, \mathrm{P}$, and $\mathrm{O}),{ }^{[4]} \mathrm{C}-\mathrm{F}$ and $\mathrm{C}-\mathrm{O}$ bond activation, ${ }^{[5]}$ whereas their use as ligand in coordination chemistry is rather limited. In contrast, LGa has been widely applied as terminal ligand in transition metal complexes, ${ }^{[6]}$ whereas its activity in bond activation reactions of unsaturated organic molecules is rather limited, most likely resulting from the more weakly reducing character of LGa compared to LAl. However, LGa was found to insert into $\mathrm{E}-\mathrm{X}$ bonds of various elements including $\mathrm{H}-\mathrm{H}, \mathrm{N}-\mathrm{H}$ and $\mathrm{O}-\mathrm{H}$ bonds. ${ }^{[7]}$ Of particular interest are insertion reactions into $\mathrm{E}$ $X$ bonds of heavier main group element compounds such as $\mathrm{GaX}_{3}$ $(\mathrm{X}=\mathrm{Cl}, \mathrm{Me}),{ }^{\left[{ }^{[8]}\right.} \mathrm{Me}_{3} \mathrm{PbCl}, \mathrm{Pb}\left(\mathrm{OSO}_{2} \mathrm{CF}_{3}\right)_{2}$ and $\mathrm{Hg}\left(\mathrm{SC}_{6} \mathrm{~F}_{5}\right)_{2}{ }^{\left[{ }^{[9]}\right.}$ These reactions also yielded compounds with unusual structures and/or oxidation states, i.e. tin clusters $[\mathrm{L}(\mathrm{Cl}) \mathrm{Ga}]_{2} \mathrm{Sn}_{7}$ and $[\mathrm{L}(\mathrm{Cl}) \mathrm{Ga}]_{4} \mathrm{Sn}_{17}$, which were formed in reactions with $\mathrm{SnCl}_{2},{ }^{[10]}$ dibismuthenes $\left[\mathrm{L}(\mathrm{RO}) \mathrm{Ga}_{2} \mathrm{Bi}_{2}\left(\mathrm{R}=\mathrm{C}_{6} \mathrm{~F}_{5}, \mathrm{SO}_{2} \mathrm{CF}_{3}\right),{ }^{[11]}\right.$ which resulted from reactions with $\mathrm{Bi}(\mathrm{OR})_{3}$, or low-valent germanium complexes $(\mathrm{LGa})_{2} \mathrm{Ge}_{2}$ and $(\mathrm{LGa})_{2} \mathrm{Ge}_{4},{ }^{[12]}$ obtained from reactions of basestabilized $\mathrm{GeCl}_{2}$ with $\mathrm{LGa}$ and $\mathrm{LGa} / \mathrm{KC}_{8}$, respectively.

We recently started to investigate reactions of $L M$ with organoantimony complexes, in which the $\mathrm{Sb}-\mathrm{X}$ bond energy as well as the formal oxidation states of $\mathrm{Sb}(+\mathrm{I},+\mathrm{II},+\mathrm{III})$ were systematically varied. In contrast to reactions of $\mathrm{LM}$ with $\mathrm{BiEt}_{3}$, which occurred with insertion of $\mathrm{LM}$ into the $\mathrm{Bi}-\mathrm{C}$ bond, ${ }^{[13]}$ the analogous reaction with antimony trialkyls $\mathrm{SbR}_{3}$ failed, most likely due to the stronger $\mathrm{Sb}-\mathrm{C}$ bond. In contrast, reactions of $\mathrm{LGa}$ with $\mathrm{Sb}\left(\mathrm{NR}_{2}\right)_{3}$ and $\mathrm{SbCl}_{3}$ yielded Ga-substituted distibenes $\left[\mathrm{L}(\mathrm{X}) \mathrm{Ga}_{2} \mathrm{Sb}_{2}\left(\mathrm{X}=\mathrm{NMe}_{2}, \mathrm{NMeEt}, \mathrm{Cl}\right)\right.$ containing a central $\mathrm{Sb}=\mathrm{Sb}$ double bond. These Ga-substituted distibenes were transferred into $\left[\mathrm{L}(\mathrm{X}) \mathrm{Ga}_{2}\left(\mu, \eta^{1: 1}-\mathrm{Sb}_{4}\right)\right]\left(\mathrm{X}=\mathrm{Cl}, \mathrm{NMe}_{2}\right)$, the first $\mathrm{Sb}$ analogues of bicyclo[1.1.0]butane. ${ }^{[14]}$ Moreover, reactions of $\mathrm{LM}(\mathrm{M}=\mathrm{Al}, \mathrm{Ga}$, In) with distibines $\mathrm{R}_{4} \mathrm{Sb}_{2}(\mathrm{R}=\mathrm{Me}, \mathrm{Et})$ occurred with insertion of $\mathrm{LM}$ into the $\mathrm{Sb}-\mathrm{Sb}$ bond and formation of $\mathrm{LM}\left(\mathrm{SbEt}_{2}\right)_{2}{ }^{[15]}$ Comparable findings were reported for reactions of LAl with diphosphines, ${ }^{[16]}$ whereas the reaction of $\mathrm{LGa}$ with $\left[\mathrm{Cp}^{*} \mathrm{Sb}\right]_{4}$, in which the $\mathrm{Sb}$ atoms adopt the formal oxidation state $+\mathrm{I}$, yielded $\left[(\mathrm{LGa})_{2}\left(\mu, \eta^{2: 2}-\mathrm{Sb}_{4}\right)\right]^{[17]}$ Interestingly, analogous reactions with the stronger reducing $\mathrm{Mg}(\mathrm{I})$ reagents $\left[\mathrm{L}^{\prime} \mathrm{Mg}\right]_{2}$ occurred with formation of $\left[(\mathrm{LMg})_{4}\left(\mu_{4}, \eta^{2: 2: 2: 2}-\mathrm{Sb}_{8}\right)\right]$ and $\left[\left(\mathrm{L}^{\prime} \mathrm{Mg}\right)_{4}\left(\mu_{4}, \eta^{2: 2: 2: 2}-\mathrm{Sb}_{8}\right)\right] \quad\left\{\mathrm{L}^{\prime}=\right.$ $\left.\mathrm{HC}\left[\mathrm{C}(\mathrm{Me}) \mathrm{N}\left(2,4,6-\mathrm{Me}_{3} \mathrm{C}_{6} \mathrm{H}_{2}\right)\right]_{2}\right\},{ }^{[18]}$ containing the Zintl-type $\left[\mathrm{Sb}_{8}\right]^{4-}$

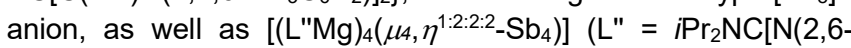
$\left.\left.i \mathrm{Pr}_{2} \mathrm{C}_{6} \mathrm{H}_{3}\right)\right]_{2}$ ) containing a $\left[\mathrm{Sb}_{4}\right]^{4-}$ tetraanion, respectively. ${ }^{[17]}$ 
In order to prove if Ga-coordinated dipnictenes of the type $[L(X) G a]_{2} E_{2}(E=P-B i)$ are generally accessible by reaction of two equivalents of $L M$ with group 15 complexes $\mathrm{EX}_{3}$, we systematically investigated reactions of LM with halide- and amide-substituted phosphines, arsines and bismuthines $\mathrm{EX}_{3}$. These reactions proceeded with formation of the double insertion products $[\mathrm{L}(\mathrm{X}) \mathrm{Ga}]_{2} \mathrm{EX}$, which is stable in case of the reactions with $\mathrm{PX}_{3}(\mathrm{X}=\mathrm{Cl}, \mathrm{Br})$, or with subsequent elimination of $\mathrm{LGaX}_{2}$ and formation of Ga-substituted dipnictenes containing $A s=A s$ and $\mathrm{Bi}=\mathrm{Bi}$ double bonds. The solid state structures of the compounds were determined by single crystal X-ray diffraction, and their bonding situation was further analyzed in detail by quantum chemical calculations.

\section{Results and Discussion}

The reactions of two equivalents $L G a$ with $\mathrm{PX}_{3}(X=\mathrm{Cl}, \mathrm{Br})$ in toluene at ambient temperature occurred with insertion of $L G a$ into two P-X bonds and formation of the stable Ga-coordinated phosphines $[L(X) G a]_{2} P X(X=C l 1, B r 2)$, which were isolated as pale green (1) and pale yellow crystalline solids (2) after workup (Scheme 1). Similar twofold insertion reactions of a germylene in the $\mathrm{P}-\mathrm{Cl}$ bonds of $\left(\mathrm{Me}_{2} \mathrm{~N}\right) \mathrm{PCl}_{2}$ have recently been reported. ${ }^{[19]}$ In contrast, no reaction was observed for the analogous reaction of LGa with $\mathrm{P}\left(\mathrm{NMe}_{2}\right)_{3}$ even at high reaction temperatures up to $125^{\circ} \mathrm{C}$ and prolonged reaction times $(24 \mathrm{~h})$ in toluene.
The influence of the substituent on the reactivity of the arsines can clearly be seen, since the reaction of $\mathrm{LGa}$ with $\mathrm{AsCl}_{3}$ and $\mathrm{Me}_{2} \mathrm{NAsCl}_{2}$ occurred smoothly at ambient temperature within minutes, whereas that with $\mathrm{As}\left(\mathrm{NMe}_{2}\right)_{3}$ required much harsher reaction conditions and the formation of the corresponding diarsene $\left[\mathrm{L}\left(\mathrm{Me}_{2} \mathrm{~N}\right) \mathrm{Ga}\right]_{2} \mathrm{As}_{2}$ (5) was only finished after heating the solution up to $165{ }^{\circ} \mathrm{C}$ for five days (Fig. S22). In contrast, the analogous reaction with $\mathrm{LAl}$ yielded $\left[\mathrm{L}\left(\mathrm{Me}_{2} \mathrm{~N}\right) \mathrm{Al}\right]_{2} \mathrm{As}_{2}$ (6) after heating at $80{ }^{\circ} \mathrm{C}$ for one day, clearly demonstrating the higher reduction potential of LAl compared to LGa (Scheme 2 ).<smiles></smiles>

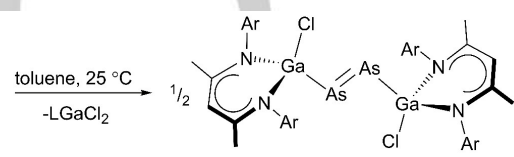

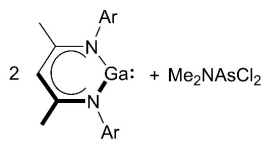

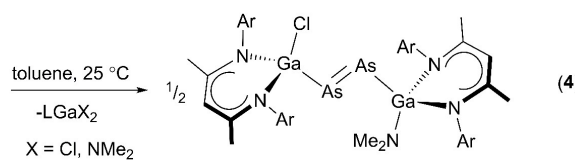

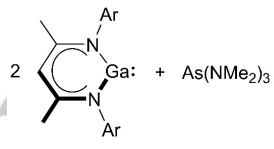

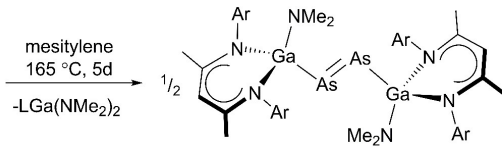

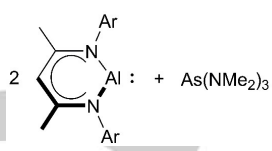

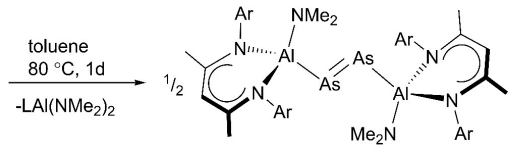

Scheme 2. Synthesis of 3-6.

Finally, the reactions of LGa with several Bi amides were studied (Scheme 3). While the reaction of two equivalents of $L G a$ with $\mathrm{Bi}\left(\mathrm{NMe}_{2}\right)_{3}$ only yielded $\mathrm{Bi}$ metal and $\mathrm{LGa}\left(\mathrm{NMe}_{2}\right)_{2}$ (as confirmed by ${ }^{1} \mathrm{H}$ NMR spectroscopy, Figure S23) even at low temperatures, that with sterically more pronounced $\mathrm{Bi}\left(\mathrm{NEt}_{2}\right)_{3}$ gave $\left[\mathrm{L}\left(\mathrm{Et}_{2} \mathrm{~N}\right) \mathrm{Ga}_{2} \mathrm{Bi}_{2}(7)\right.$ in good yields. $\left[\mathrm{L}\left(\mathrm{Et}_{2} \mathrm{~N}\right) \mathrm{Ga}_{2} \mathrm{Bi}_{2}(7)\right.$ was formed at milder reaction conditions $\left(25^{\circ} \mathrm{C}, 4\right.$ days) compared to the diarsene $\left[\mathrm{L}\left(\mathrm{Me}_{2} \mathrm{~N}\right) \mathrm{Ga}_{2} \mathrm{As}_{2}\right.$ (5), which clearly results from the weaker $\mathrm{Bi}-\mathrm{N}$ bond compared to the As-N bond. It should further be mentioned that the analogous reaction of $\mathrm{LGa}$ with $\mathrm{Sb}(\mathrm{NMeEt})_{3}$ required heating at $60{ }^{\circ} \mathrm{C}$ in the absence of any solvents for seven days, whereas the reaction with the sterically less hindered $\mathrm{Sb}\left(\mathrm{NMe}_{2}\right)_{3}$ proceeded already very slowly at ambient temperature, but is finished after heating to $75^{\circ} \mathrm{C}$ for 24 h. ${ }^{[14]}$ In contrast, no reaction between LGa and the sterically more demanding $\mathrm{Sb}\left(\mathrm{NEt}_{2}\right)_{3}$ was observed, even after prolonged heating at $120{ }^{\circ} \mathrm{C}$. Analogous trends were observed for the reactions of two equivalents of $\mathrm{LGa}$ with $\mathrm{ECl}_{3}(\mathrm{E}=\mathrm{As}, \mathrm{Sb}, \mathrm{Bi})$. The reaction with $\mathrm{AsCl}_{3}$ occurred at ambient temperature, whereas that with $\mathrm{SbCl}_{3}$ is finished within minutes already at $0{ }^{\circ} \mathrm{C}$. In contrast, the reaction with $\mathrm{BiCl}_{3}$ occurred slowly at ambient temperature with formation of elemental bismuth as well as $\mathrm{LGaCl}_{2}$, but we could not prove if this reaction proceeds via formation of an thermally unstable dibismuthene $\left[\mathrm{L}(\mathrm{Cl}) \mathrm{Ga}_{2} \mathrm{Bi}_{2}\right.$ or if $\mathrm{BiCl}_{3}$ is directly reduced to $\mathrm{Bi}$. However, these experimental findings clearly reveal the strong influence of the strength of the 
$\mathrm{E}-\mathrm{X}(\mathrm{X}=\mathrm{Cl}, \mathrm{N})$ bond as well as the steric demand of the amido $\left(\mathrm{NR}_{2}\right)$ substituent.

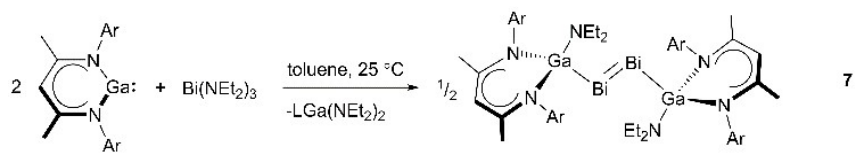

Scheme 3. Synthesis of 7.

Isolated $\mathbf{1 - 7}$ are thermally stable and can be stored in a glove box under Ar atmosphere for several months. The thermal stability of the compounds differ significantly. 1, 2, 4 and 6 melt without decomposition at $222{ }^{\circ} \mathrm{C}(2), 239^{\circ} \mathrm{C}(4)$ and $275^{\circ} \mathrm{C} \mathrm{(6)}$, while 3 and 7 decomposes at $255^{\circ} \mathrm{C}(3)$ and $120^{\circ} \mathrm{C}(7)$, respectively, without melting.

Solution-phase characterization. 1 and $\mathbf{2}$ dissolve moderately in benzene, toluene and hexane, whereas 3 - $\mathbf{7}$ dissolve poorly in benzene and toluene and are insoluble in hexane. The ${ }^{1} \mathrm{H}$ NMR spectrum of $\mathbf{1}$ and $\mathbf{2}$ in toluene- $\mathrm{d}_{8}$ show the expected septets and doublets for the $i \operatorname{Pr}$ groups of the $\beta$-diketiminate ligand as well as single resonances of the $\mathrm{y}-\mathrm{CH}$ and two methyl groups of the $\beta$ diketiminate ligand (Table 1). These findings are confirmed by the ${ }^{13} \mathrm{C}$ NMR spectrum, which only shows the expected resonances of the $\beta$-diketiminate groups. The ${ }^{31} \mathrm{P}$ NMR spectra of $\mathbf{1}$ and 2 show single resonances at 0.52 (1) and $-42.9 \mathrm{ppm}$ (2), which prove the formation of a phosphine rather than a diphosphene. Diphosphenes of the type $\mathrm{R}_{2} \mathrm{P}_{2}{ }^{[20]}$ and metal-substituted diphosphenes such as $\left[\left({ }^{\mathrm{Me}} \mathrm{PDI}\right) \mathrm{IrCO}\right]_{2}\left(\mu-\mathrm{P}_{2}\right) \quad(\mathrm{PDI}=$ pyridinediimine $)$ and $\left[(\text { silox })_{3} M\right]_{2}\left(\mu: \eta^{1}, \eta^{1}-P_{2}\right)(M=N b, T a)$ typically exhibit resonances between 440 and 550 ppm..$^{[21]}$ Heating a solution of $[\mathrm{L}(\mathrm{Cl}) \mathrm{Ga}]_{2} \mathrm{PCl}(\mathbf{1})$ in toluene- $\mathrm{d}_{8}$ at $125{ }^{\circ} \mathrm{C}$ for $5 \mathrm{~d}$ resulted in the formation of several new phosphorous species, but the formation of a diphosphene was excluded due to the lack of any resonances in the typical range. However, two new triplets at -187.4 and $338.1 \mathrm{ppm}\left({ }^{1} \mathrm{~J}_{P P}=140 \mathrm{~Hz}\right)$ in the ${ }^{31} \mathrm{P}$ NMR spectrum (Figure S25), which appear in the typical range for tetraphosphabicyclobutanes $\mathrm{R}_{2} \mathrm{P}_{4}$, ${ }^{[22]}$ show the formation of $\left[\mathrm{L}(\mathrm{Cl}) \mathrm{Ga}_{2} \mathrm{P}_{4}\right.$ as was previously observed for $\left[\mathrm{L}(\mathrm{Cl}) \mathrm{Ga}_{2} \mathrm{Sb}_{4}{ }^{[14]}\right.$ In addition, the in situ ${ }^{1} \mathrm{H}$ NMR spectrum shows the formation of $\mathrm{LGaCl}_{2}$ as by-product as was also observed for the formation of $\left[\mathrm{L}(\mathrm{Cl}) \mathrm{Ga}_{2} \mathrm{Sb}_{4}\right.$.

The ${ }^{1} \mathrm{H}$ NMR spectra of $\mathbf{3}$ to $\mathbf{7}$ are very similar and each show two septets and four doublets for the magnetically inequivalent $i \mathrm{Pr}$ groups of the $\beta$-diketiminate ligand as was previously observed for the corresponding distibenes $[\mathrm{L}(\mathrm{X}) \mathrm{Ga}]_{2} \mathrm{Sb}_{2}\left(\mathrm{X}=\mathrm{Cl}, \mathrm{NMe}_{2}\right),{ }^{[14]}$ while the $\mathrm{y}-\mathrm{CH}$ and two methyl groups of the $\mathrm{C}_{3} \mathrm{~N}_{2} \mathrm{M}$ ring exhibit only single resonances. The ${ }^{13} \mathrm{C}$ NMR spectra of $\mathbf{1}, 2,3$ and 6 show the expected 15 resonances of the $\beta$-diketiminate groups, whereas unsymmetrical 4 shows only 29 of the expected 30 resonances of the $\beta$-diketiminate groups (Figure S13) and two additional resonances of the $\mathrm{NMe}_{2}$ group. However, the resonance at $24.8 \mathrm{ppm}$ appears with twofold intensity, indicating an overlap of two signals, which is supported by the fact that only 7 resonances instead of eight are observed for the iPr groups.

$\mathbf{1 - 4}$ and $\mathbf{6}$ are stable in toluene solutions and don't show any kind of decomposition up to temperatures of $80^{\circ} \mathrm{C}$. A solution of 7 in toluene also doesn't show any sign of light sensitivity and can be stored for weeks at ambient temperature without decomposition, whereas it decomposes gradually at elevated temperatures even in the dark with precipitation of $\mathrm{Bi}$ metal and formation of unidentified reaction products.

Table 1. ${ }^{1} \mathrm{H}$ NMR chemical shifts of $1-4,6$ and 7 .[a]

\begin{tabular}{|c|c|c|c|c|c|}
\hline & $Y-\mathrm{CH}$ & $\mathrm{CHMe} 2$ & $\mathrm{CH} \mathrm{Me}_{2}$ & $\mathrm{CMe}$ & $N R_{2}$ \\
\hline $1^{[b]}$ & 4.81 & $3.55,3.22$ & $\begin{array}{l}1.21,1,18 \\
0.98\end{array}$ & 1.46 & --- \\
\hline $2^{[b]}$ & 4.87 & $3.63,3.24$ & $\begin{array}{l}1.25,1.20 \\
0.96\end{array}$ & 1.47 & --- \\
\hline $3^{[\mathrm{b}]}$ & 4.85 & $3.77,2.90$ & $\begin{array}{l}1.35,1.24 \\
1.09,0.97\end{array}$ & 1.61 & --- \\
\hline $4^{[b]}$ & $4.87,4.72$ & $\begin{array}{l}3.77, \\
3.54, \\
3.17,2.77\end{array}$ & $\begin{array}{l}1.31,1.21 \\
1.13,1.02 \\
0.98,0.97\end{array}$ & $\begin{array}{l}1.63 \\
1.60\end{array}$ & $\begin{array}{l}2.95 \\
2.37\end{array}$ \\
\hline $6^{[\mathrm{b}]}$ & 4.92 & $3.53,2.93$ & $\begin{array}{l}1.28,0.99 \\
0.96\end{array}$ & 1.61 & $\begin{array}{l}2.69 \\
2.36\end{array}$ \\
\hline $7^{[c]}$ & 4.74 & $2.77,4.07$ & $\begin{array}{l}1.05,1.11 \\
1.29,1.39\end{array}$ & 1.58 & $\begin{array}{l}1.02, \\
1.36, \\
2.80, \\
3.72\end{array}$ \\
\hline
\end{tabular}

[a] NMR spectra of $\mathbf{5}$ couldn't be recorded due to its poor solubility in organic solvents; $[b]$ in toluene- $d_{8},[c]$ in benzene- $d_{6}$

Solid state structures. The molecular structures of $2 \cdot 2 \mathrm{C}_{7} \mathrm{H}_{8}, \mathbf{3}$, 4, 6 and 7 were determined by single crystal $X$-ray diffraction. Single crystals were obtained from saturated solutions in toluene upon storage at $-30{ }^{\circ} \mathrm{C}$ for 3 days $(2)$, at $0{ }^{\circ} \mathrm{C}(3)$ or at room temperature for 2 days (7) and 3 days (4 and $\mathbf{6}) \cdot \mathbf{2} \cdot \mathbf{2} \mathrm{C}_{7} \mathrm{H}_{8}$ crystallizes in the monoclinic space group $P 2_{1} / c$ with the molecule and two disordered toluene molecules in general positions (Figure 1). Since the central $\mathrm{P}-\mathrm{Br}$ unit is disordered over three positions with the atomic displacement parameters of the corresponding atoms still large, a meaningful quantitative discussion of this part of the molecule is not feasible. The Ga-Br bond lengths (Table 2) of the three disordered units slightly differ. The Ga atoms adopt distorted tetrahedral coordination spheres and the $\beta$-diketiminate ligands deviate from planarity as is typical for $L G a X$ fragments. 


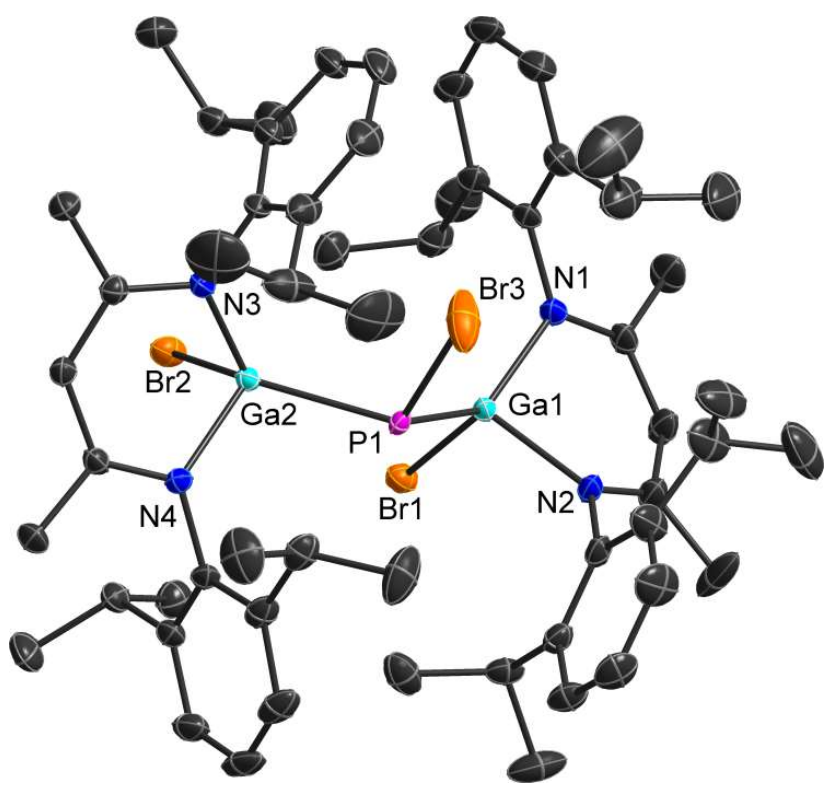

Figure 1. Molecular structure of $[\mathrm{L}(\mathrm{Br}) \mathrm{Ga}]_{2} \mathrm{PBr}$ in the crystal of $\mathbf{2} \cdot \mathbf{2} \mathrm{C}_{7} \mathrm{H}_{\mathbf{8}} . \mathrm{H}-$ atoms and minor components of the disordered $\mathrm{PBr}$ and $i \mathrm{Pr}$ units as well as the disordered solvent molecules were omitted for clarity. Displacement ellipsoids are drawn at the $50 \%$ probability level.

The metal-substituted diarsene $\left[\mathrm{L}(\mathrm{Cl}) \mathrm{Ga}_{2} \mathrm{As}_{2}\right.$ (3) crystallizes monoclinic with space group $P 2_{1} / n$, while $[\mathrm{L}(\mathrm{Cl}) \mathrm{Ga}] \mathrm{As}=\mathrm{As}\left[\mathrm{Ga}\left(\mathrm{NMe}_{2}\right) \mathrm{L}\right] \quad(4)$ and $\left[\mathrm{L}\left(\mathrm{Me}_{2} \mathrm{~N}\right) \mathrm{Al}\right]_{2} \mathrm{As}_{2} \quad$ (6) crystallize in the triclinic space group $P-1$ (Figures 2 - 4). 3 and 4 are located on centers of inversion.

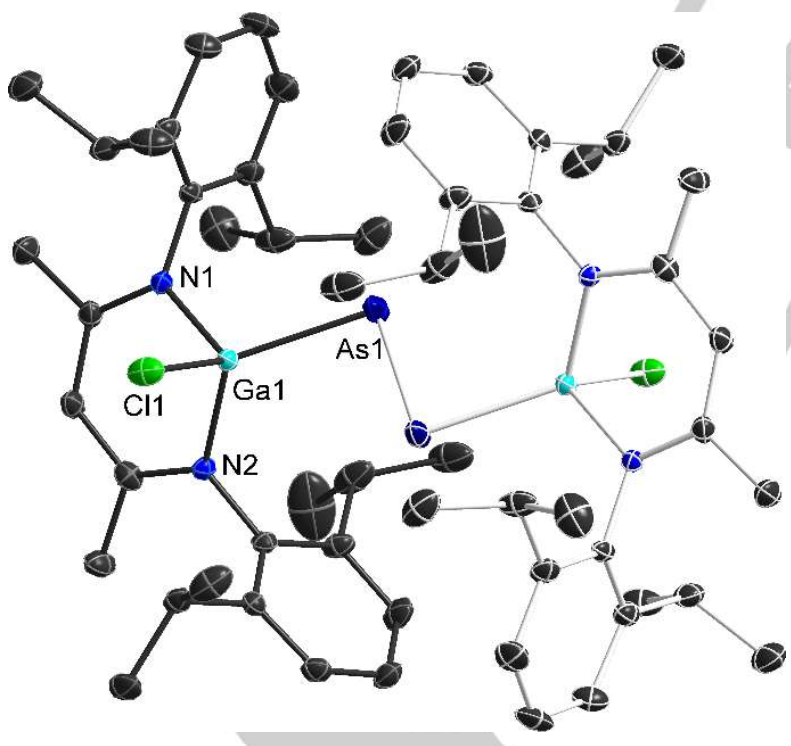

Figure 2. Molecular structure of $[\mathrm{L}(\mathrm{Cl}) \mathrm{Ga}]_{2} \mathrm{As}_{2}$ in the crystal of $3 . \mathrm{H}$-atoms were omitted for clarity. Displacement ellipsoids are drawn at the $50 \%$ probability level and the symmetry generated part of the molecule is depicted in pale colors $(-x$, $2-y,-z)$.
Since the point group symmetry of the molecule of $\mathbf{4}$ does not match the site symmetry, the $\mathrm{Cl}$ and $\mathrm{NMe}_{2}$ substituents are superimposed. Refinement in a space group of lower symmetry did not yield an acceptable model.

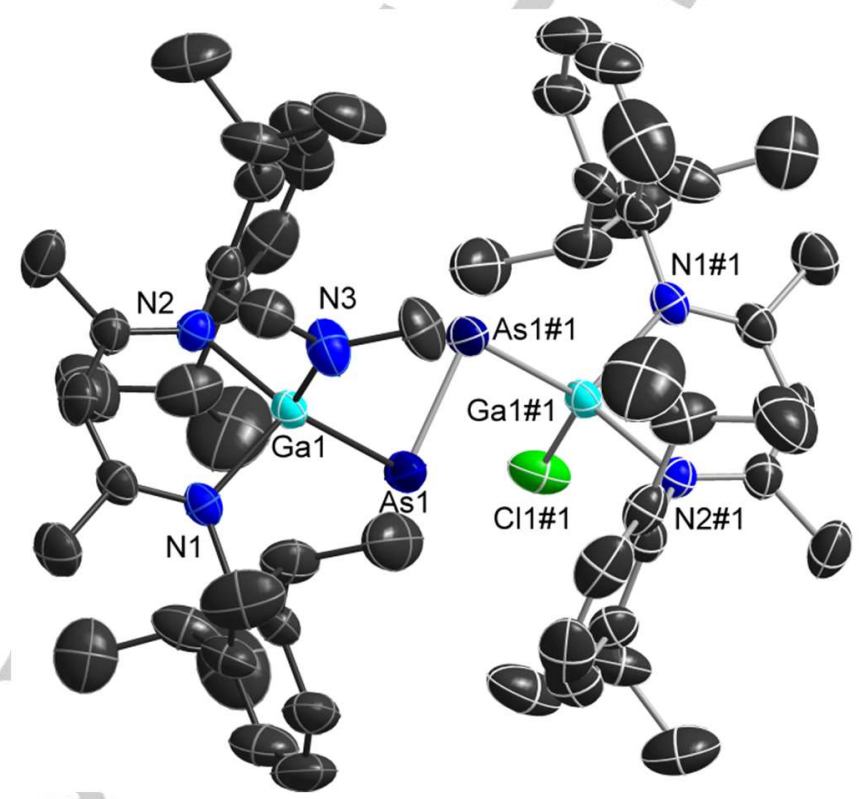

Figure 3. Molecular structure of $[\mathrm{L}(\mathrm{Cl}) \mathrm{Ga}] \mathrm{As}=\mathrm{As}\left[\mathrm{Ga}\left(\mathrm{NMe}_{2}\right) \mathrm{L}\right]$ in the crystal of 4 $\mathrm{H}$-atoms were omitted for clarity. Displacement ellipsoids are drawn at the $50 \%$ probability level and the symmetry generated part of the molecule is depicted in pale colors (\#1 1-x, 1-y, -z). Cl and the $\mathrm{NMe}_{2}$ group are disordered by inversion symmetry and only one of the positions is shown.

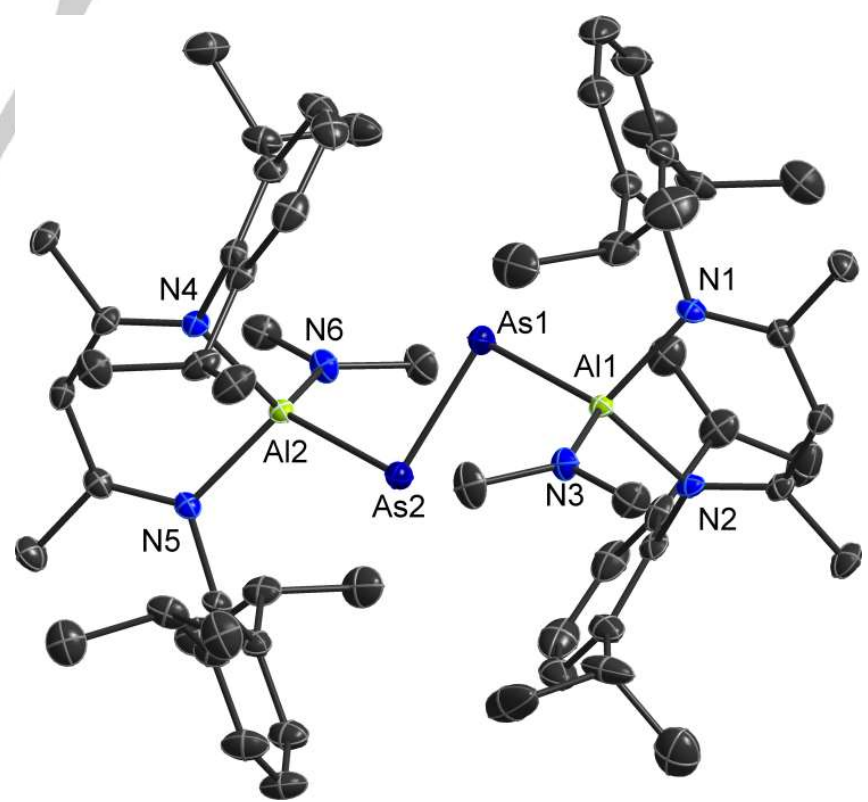

Figure 4. Molecular structure of $\left[\mathrm{L}\left(\mathrm{Me}_{2} \mathrm{~N}\right) \mathrm{Al}_{2} \mathrm{As}_{2}\right.$ in the crystal of 6 . $\mathrm{H}$-atoms were omitted for clarity. Displacement ellipsoids are drawn at the $50 \%$ probability level. 
The dibismuthene $\left[\mathrm{L}\left(\mathrm{Et}_{2} \mathrm{~N}\right) \mathrm{Ga}_{2} \mathrm{Bi}_{2} \quad\right.$ (7) crystallizes in the monoclinic space group $P 2_{1} / n$ and is also placed on a center of inversion (Figure 5).

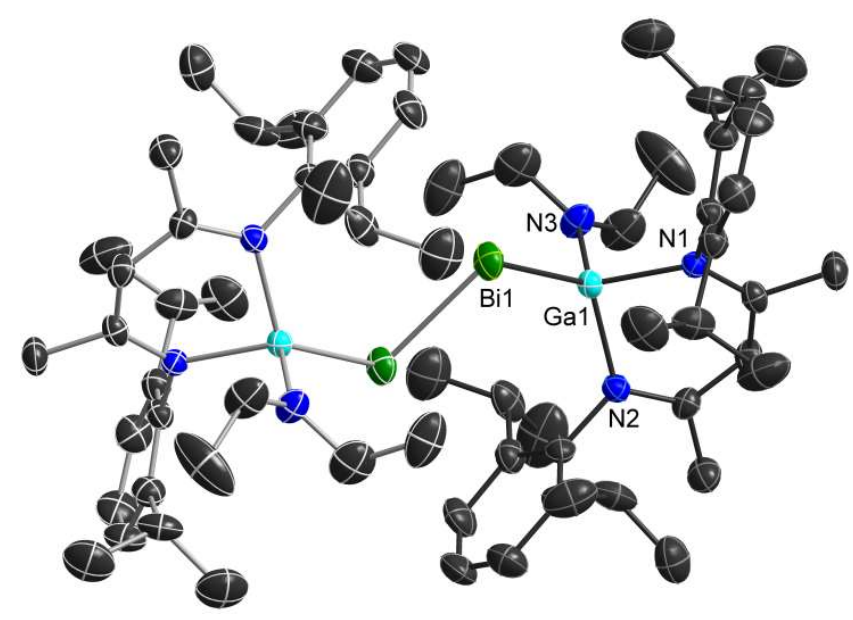

Figure 5. Molecular structure of $\left[\mathrm{L}\left(\mathrm{Et}_{2} \mathrm{~N}\right) \mathrm{Ga}_{2} \mathrm{Bi}_{2}\right.$ in the crystal of 7 . $\mathrm{H}$-atoms and the minor occupied carbon atom positions of the disordered ethyl group at N3 were omitted for clarity. Displacement ellipsoids are drawn at the $50 \%$ probability level and the symmetry generated part of the molecule is depicted in pale colors (symmetry operation $1-x, 1-y,-z$ )

Compared to the analogous distibene structures $\left[\mathrm{L}(\mathrm{X}) \mathrm{Ga}_{2} \mathrm{Sb}_{2}(\mathrm{X}\right.$ $\left.=\mathrm{Cl}, \mathrm{NMe}_{2}, \mathrm{NMeEt}\right),{ }^{[14]}$ neither changing $\mathrm{M}(\mathrm{Al}, \mathrm{Ga})$ nor $\mathrm{E}(\mathrm{As}, \mathrm{Sb}$, $\mathrm{Bi})$ strongly influences the overall conformation of the molecule. The As atoms in $\left[\mathrm{L}(\mathrm{Cl}) \mathrm{Ga}_{2} \mathrm{As}_{2}(3),[\mathrm{L}(\mathrm{Cl}) \mathrm{Ga}] \mathrm{As}=\mathrm{As}\left[\mathrm{Ga}\left(\mathrm{NMe}_{2}\right) \mathrm{L}\right]\right.$ (4) and $\left[\mathrm{L}\left(\mathrm{Me}_{2} \mathrm{~N}\right) \mathrm{Al}\right]_{2} \mathrm{As}_{2}(6)$ are slightly further off the plane formed by the ligands' backbones (offset from best plane of the backbones: 0.195(6) $\AA(3), 0.4097(13) \AA(4), 0.4503(8)$ and $0.5168(8) \AA(6), 0.0192(23) \AA(7))$. The As=As bond lengths in 3 (2.2556(6) $\AA$ ), 4 (2.2554(8) $\AA$ ) and 6 (2.2707(4) $\AA$ ) are comparable to those reported for diarsenes of the general type RAs=AsR (2.219 - $2.358 \AA$; mean bond length $2.271 \AA$ ) , ${ }^{[23]}$ but shorter compared to the heavier congeners $[\mathrm{L}(\mathrm{X}) \mathrm{Ga}]_{2} \mathrm{Sb}_{2}\left(\mathrm{X}=\mathrm{Cl}, \mathrm{NMe}_{2}\right.$, $\mathrm{NMeEt})$ and $\left[\mathrm{L}\left(\mathrm{Et}_{2} \mathrm{~N}\right) \mathrm{Ga}_{2} \mathrm{Bi}_{2}(7)(2.8132(5) \AA)\right.$. In addition, the $\mathrm{E}$ $\mathrm{E}$ bond distances in $\mathbf{3}-\mathbf{7}$ are shorter than the sum of the calculated atomic radii [1.21 (As), $1.40(\mathrm{Sb}), 1.51 \AA(\mathrm{Bi}){ }^{[24]} 1.31$ (As), $\left.1.46(\mathrm{Sb}), 1.50 \AA(\mathrm{Bi})^{[25]}\right]$, most likely due to the lower coordination number (c.n. 2) of $\mathbf{3}-\mathbf{7}$ compared to the calculated values (c.n. 3).

The Bi-Bi bond length of $\left[\mathrm{L}\left(\mathrm{Et}_{2} \mathrm{~N}\right) \mathrm{Ga}_{2} \mathrm{Bi}_{2}(7)\right.$ matches well with those of $\left[\mathrm{L}(\mathrm{RO}) \mathrm{Ga}_{2} \mathrm{Bi}_{2}\left(\mathrm{R}=\mathrm{C}_{6} \mathrm{~F}_{5} 2.8182(4) \AA ; \mathrm{SO}_{2} \mathrm{CF}_{3} 2.8111(2)\right.\right.$ $\AA)^{[11]}$ and other dibismuthenes found in the CSD database $(2.796$ - $2.893 \AA$; mean bond length $2.831 \AA$ ). ${ }^{[26]}$ However, the Ga-Bi (2.7061(6) $\AA$ ) and Ga-N1/2 bonds (av. $2.006 \AA$ ) in 7 are slightly elongated compared to those in $\left[\mathrm{L}(\mathrm{RO}) \mathrm{Ga}_{2} \mathrm{Bi}_{2}\left(\mathrm{R}=\mathrm{C}_{6} \mathrm{~F}_{5}: \mathrm{Ga}-\mathrm{Bi}\right.\right.$ 2.693(6) $\AA$, av. Ga-N $1.952 \AA ; \mathrm{SO}_{2} \mathrm{CF}_{3}$ : Ga-Bi 2.655(1) $\AA$, av. Ga$\mathrm{N} 1.928 \AA$ ), which can be attributed to the weaker electronwithdrawing nature of the $\mathrm{NEt}_{2}$ group in $\left[\mathrm{L}\left(\mathrm{Et}_{2} \mathrm{~N}\right) \mathrm{Ga}_{2} \mathrm{Bi}_{2}\right.$ (7) compared to the OR groups in $\left[\mathrm{L}(\mathrm{RO}) \mathrm{Ga}_{2} \mathrm{Bi}_{2}\right.$.
Table 2. Comparison of bond lengths $(\AA)$ and angles $\left(^{\circ}\right)$ in 2, 3, 4, 6 and 7.

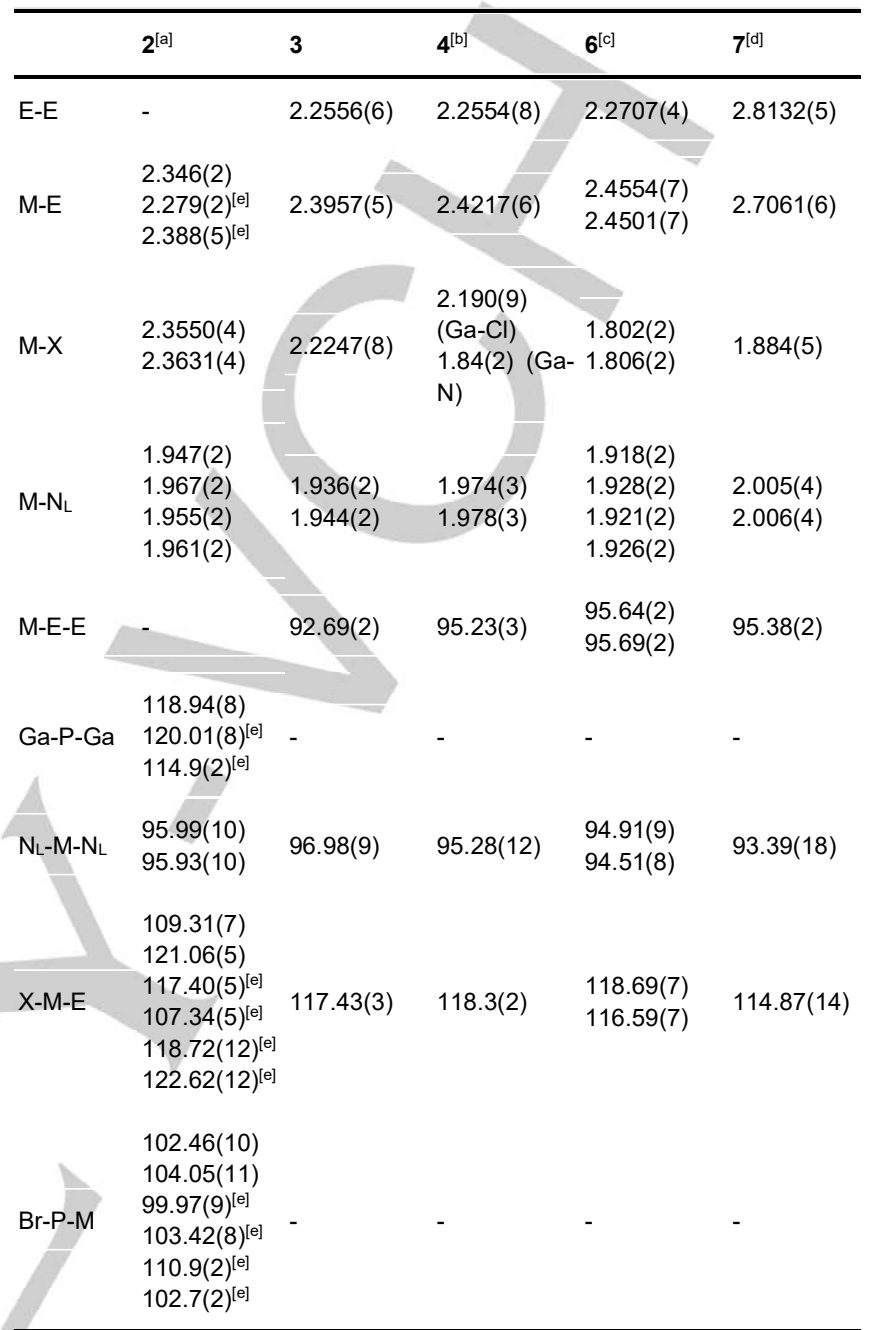

[a] $\mathrm{M}=\mathrm{Ga}, \mathrm{X}=\mathrm{Br}$; ${ }^{[\mathrm{b}]} \mathrm{M}=\mathrm{Ga}, \mathrm{X}=\mathrm{Cl} / \mathrm{NMe}_{2} ;{ }^{[\mathrm{c}]} \mathrm{M}=\mathrm{Al}, \mathrm{X}=\mathrm{NMe}_{2} ;{ }^{[\mathrm{d}]} \mathrm{M}=$ $\mathrm{Ga}, \mathrm{X}=\mathrm{NEt}_{2} ;{ }^{\text {e] }} 2^{\text {nd }}$ and $3^{\text {rd }}$ component of the disordered part, note that $\mathrm{P}-\mathrm{Br}$ bond lengths are restrained to be equal; $\mathrm{N}_{\mathrm{L}}=\mathrm{N}$ of the $\mathrm{L}$ ligand.

Quantum chemical calculations. The bonding situations in 4, 6 and 7 were analyzed by using a number of quantum chemical techniques to gain further insight into the chemical bonding within the $\mathrm{M}_{2} \mathrm{E}_{2}(\mathrm{M}=\mathrm{Al}, \mathrm{Ga} ; \mathrm{E}=\mathrm{As}, \mathrm{Bi})$ skeletons and also to compare the results with those observed in $\left[\mathrm{L}(\mathrm{X}) \mathrm{Ga}_{2} \mathrm{Sb}_{2}(\mathrm{X}=\mathrm{Cl}\right.$, $\mathrm{NMeEt}){ }^{[14]}$ All calculated bond lengths within the $\mathrm{M}_{2} \mathrm{E}_{2}$ cores (BP86-D3/def2-SVP level of theory, ${ }^{[27-31]}$ Tables S2-S4) are in good agreement with the corresponding experimental values $(\Delta r$ $=0.01-0.05 \AA$ ).

As predicted by atoms in molecules (AIM), electron localization function (ELF), and natural bond orbital (NBO) analyses, ${ }^{[32-35]}$ the E-E bonds in 4, 6 and 7 are covalent (Tables S2-S4, Figures 68 ), in accordance to reported computational data for pnictogencontaining species. ${ }^{[36]}$ 
(a)

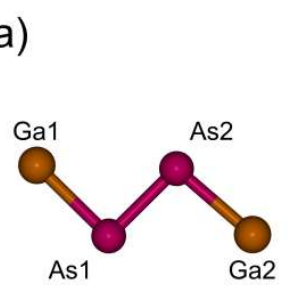

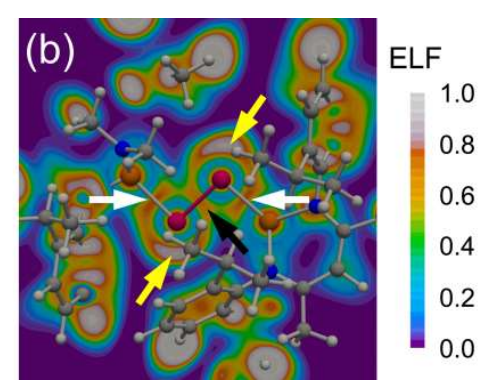

Figure 6. (a) Atomic labelling for the $\mathrm{Ga}_{2} \mathrm{As}_{2}$ skeleton and (b) ELF distribution in $[\mathrm{L}(\mathrm{Cl}) \mathrm{Ga}] \mathrm{As}=\mathrm{As}\left[\mathrm{Ga}\left(\mathrm{NMe}_{2}\right) \mathrm{L}\right](4)$ in the Ga1-As1-As2 plane. $\mathrm{V}(\mathrm{Ga}, \mathrm{As}), \mathrm{V}(\mathrm{As})$ and $\mathrm{V}(\mathrm{As}, \mathrm{As})$ basins are indicated by white, yellow, and black arrows, respectively. (a)

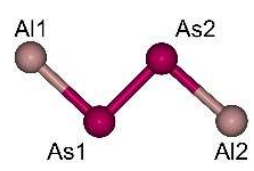

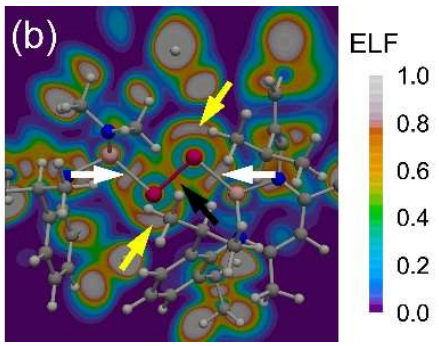

Figure 7. (a) Atomic labelling for the $\mathrm{Al}_{2} \mathrm{As}_{2}$ skeleton and (b) ELF distribution in $\left[\mathrm{L}\left(\mathrm{Me}_{2} \mathrm{~N}\right) \mathrm{Al}_{2} \mathrm{As}_{2}(6)\right.$ in the Al1-As1-As2 plane. $\mathrm{V}(\mathrm{Al}, \mathrm{As}), \mathrm{V}(\mathrm{As})$, and $\mathrm{V}(\mathrm{As}, \mathrm{As})$ basins are indicated by white, yellow, and black arrows, respectively.
$(\mathrm{ON}=2.0|\mathrm{e}|)$ that are polarized toward the pnictogen end. The polarity of M-E bonds is increased in the order $\mathrm{Ga}-\mathrm{Bi}<\mathrm{Ga}-\mathrm{As}<$ $\mathrm{Al}-\mathrm{As}$ as can be seen from the values of polarization coefficients $\left(\left|C_{M}\right|^{2} ; 43-44 \%>34-38 \%>27-28 \%\right)$, the contributions of the electrons of $M$ into the $V(M, E)$ basins according to ELF/AIM intersection procedure $(\bar{N}[\mathrm{~V}(\mathrm{M}, \mathrm{E}) \mid \mathrm{M}] ; 1.2-1.3 e>1.0-1.2 e>$ $0.3 e),{ }^{[37]}$ and the differences between natural population analysis (NPA) partial charges on $M$ and $E(\Delta q ; 1.3|e|<1.4-1.6|e|<$ $2.0|e|)$. AIM analysis suggests shared $\mathrm{Ga}-\mathrm{As}$ interactions $\left(\nabla^{2} \rho\left(\mathbf{r}_{\mathrm{b}}\right)<0 ;\left|V\left(\mathbf{r}_{\mathrm{b}}\right)\right| / G\left(\mathbf{r}_{\mathrm{b}}\right)>2, H\left(\mathbf{r}_{\mathrm{b}}\right)<0\right)$ and intermediate Al-As and Ga-Bi interactions $\left(\nabla^{2} \rho\left(\mathbf{r}_{\mathrm{b}}\right)>0 ; 1<\left|V\left(\mathbf{r}_{\mathrm{b}}\right)\right| / G\left(\mathbf{r}_{\mathrm{b}}\right)<2, H\left(\mathbf{r}_{\mathrm{b}}\right)<0\right)$.

It should be noted that the same bonding pattern was observed for $\mathrm{Ga}_{2} \mathrm{Sb}_{2}$ cores in closely related distibene complexes. ${ }^{[14]}$ Wiberg bond indices (WBIs) calculated for 4, 6, 7 as well as $\left[\mathrm{L}(\mathrm{Cl}) \mathrm{Ga}_{2} \mathrm{Sb}_{2}\right.$ and $\left[\mathrm{L}(\mathrm{MeEtN}) \mathrm{Ga}_{2} \mathrm{Sb}_{2}\right.$ (Tables S2-S4) indicate double and single bond character for all $\mathrm{E}-\mathrm{E}(\mathrm{WBI}=1.8)$ and $\mathrm{M}-$ $\mathrm{E}(\mathrm{WBI}=0.8-1.0)$ bonds, respectively, confirming common chemical bonding picture within $\mathrm{M}_{2} \mathrm{E}_{2}$ units. The energies of frontier molecular orbitals (Figure S22) give HOMO-LUMO gaps ranging between $5.55(7)-6.27(4) \mathrm{eV}$. Ionization potentials of $\left[(\mathrm{LMX})_{2} \mathrm{E}_{2}\right]$ compounds, which can be estimated as $-E(\mathrm{HOMO})$ according to Koopmans' theorem, are decreased in the order $[\mathrm{L}(\mathrm{Cl}) \mathrm{Ga}]_{2} \mathrm{Sb}_{2}<\mathbf{4}<\left[\mathrm{L}(\mathrm{MeEtN}) \mathrm{Ga}_{2} \mathrm{Sb}_{2}<\mathbf{6}<\mathbf{7}\right.$.

\section{Conclusions}

In summary, reactions of LGa with phosphorus, arsenic and bismuth halides and amides were studied, revealing clear trends in the reactivity as well as different reaction pathways. The reaction of $\mathrm{LGa}$ with $\mathrm{PX}_{3}(\mathrm{X}=\mathrm{Cl}, \mathrm{Br})$ stopped after twofold insertion into the $P-X$ bonds and formation of $[L(X) G a]_{2} P X(X=C l$ 1, $\mathrm{Br} 2$ ), whereas the analogous reactions with $\mathrm{AsCl}_{3}, \mathrm{Me}_{2} \mathrm{NAsCl}_{2}$ and $\mathrm{As}\left(\mathrm{NMe}_{2}\right)_{3}$ further proceeded with elimination of $\mathrm{LGaX}_{2}(\mathrm{X}=$ $\mathrm{Cl}, \mathrm{NMe}_{2}$ ) and subsequent formation of the corresponding diarsenes $\left[\mathrm{L}(\mathrm{Cl}) \mathrm{Ga}_{2} \mathrm{As}_{2}(3),[\mathrm{L}(\mathrm{Cl}) \mathrm{Ga}]_{2} \mathrm{As}_{2}\left[\mathrm{Ga}\left(\mathrm{NMe}_{2}\right) \mathrm{L}\right](\mathbf{4})\right.$, and $\left[\mathrm{L}\left(\mathrm{Me}_{2} \mathrm{~N}\right) \mathrm{Ga}\right]_{2} \mathrm{As}_{2}$ (5). The reaction of $\mathrm{LGa}$ with $\mathrm{As}\left(\mathrm{NMe}_{2}\right)_{3}$ required very harsh conditions $\left(165^{\circ} \mathrm{C}, 5 \mathrm{~d}\right)$, whereas the reaction with stronger $\sigma$-donor and stronger reducing agent $L A$ l already proceeded at $80{ }^{\circ} \mathrm{C}$ and yielded $\left[\mathrm{L}(\mathrm{Cl}) \mathrm{Al}_{2} \mathrm{As}_{2}(6)\right.$ after 1 day. Finally, the reaction of $\mathrm{LGa}$ with $\mathrm{Bi}\left(\mathrm{NEt}_{2}\right)_{3}$ also occurred with insertion and elimination of $\mathrm{LGa}\left(\mathrm{NEt}_{2}\right)_{2}$ and formation of the corresponding Ga-substituted dibismuthene $\left[\mathrm{L}\left(\mathrm{Et}_{2} \mathrm{~N}\right) \mathrm{Ga}_{2} \mathrm{Bi}_{2}(7) .2\right.$, 3, 4, 6 and 7 were structurally characterized by single crystal $X-$ ray diffraction and the bonding situation, which was investigated by quantum chemical calculations, clearly revealed the double bond character within these complexes.

\section{Experimental Section}

Figure 8. (a) Atomic labelling for the $\mathrm{Ga}_{2} \mathrm{Bi}_{2}$ skeleton and (b) ELF distribution in $\left[\mathrm{L}\left(\mathrm{Et}_{2} \mathrm{~N}\right) \mathrm{Ga}_{2} \mathrm{Bi}_{2}(7)\right.$ in the $\mathrm{Ga} 1-\mathrm{Bi} 1-\mathrm{Bi} 2$ plane. $\mathrm{V}(\mathrm{Ga}, \mathrm{Bi}), \mathrm{V}(\mathrm{Bi})$, and $\mathrm{V}(\mathrm{Bi}, \mathrm{Bi})$ basins are indicated by white, yellow, and black arrows, respectively.

Covalent M-E bonds are characterized by disynaptic $V(M, E)$ basins populated by $2.3-2.4 e$ and $\sigma_{\mathrm{M}-\mathrm{E}}$ bond orbitals
General Procedures. The reactions were performed in purified argon atmosphere using standard Schlenk and glove-box techniques. Solvents were dried using a MBraun Solvent Purification System and carefully degassed. Karl Fischer titration of the dry solvents show values less than $3 \mathrm{ppm}$. Deuterated NMR solvents were stored over activated molecular sieves $(4 \AA)$ and degassed prior to use. $\mathrm{LGa},{ }^{[38]} \mathrm{LAl},{ }^{[39]} \mathrm{As}\left(\mathrm{NMe}_{2}\right)_{3},{ }^{[40]}$ and 
$\mathrm{Bi}\left(\mathrm{NEt}_{2}\right)_{3}{ }^{[41]}$ were prepared according to literature methods and $\mathrm{Me}_{2} \mathrm{NAsCl}_{2}$ was prepared by a ligand exchange reaction of $\mathrm{As}\left(\mathrm{NMe}_{2}\right)_{3}$ with two equivalents of $\mathrm{AsCl}_{3} . \mathrm{PBr}_{3}$ and $\mathrm{AsCl}_{3}$ were obtained from commercial sources and purified prior to use by distillation or sublimation.

Instrumentation. The ${ }^{1} \mathrm{H}(300,500 \& 600 \mathrm{MHz}),{ }^{13} \mathrm{C}\{1 \mathrm{H}\}(75.5,125 \& 150$ $\mathrm{MHz})$ and ${ }^{31} \mathrm{P}$ NMR $(200 \mathrm{MHz})$ spectra $(\delta$ in $\mathrm{ppm})$ were recorded using a Bruker Avance DPX-300 or Bruker Avance III HD spectrometer and the spectra were referenced to internal $\mathrm{C}_{6} \mathrm{D}_{5} \mathrm{H}\left({ }^{1} \mathrm{H}: \delta=7.154 ;{ }^{13} \mathrm{C}: \delta=128.39\right)$ and $\mathrm{C}_{6} \mathrm{D}_{5} \mathrm{CHD}_{2}\left({ }^{1} \mathrm{H}: \delta=2.09 ;{ }^{13} \mathrm{C}: \delta=20.40\right)$. Microanalyses were performed at the elemental analysis laboratory of the University of Duisburg-Essen. IR spectra were measured in an ALPHA-T FT-IR spectrometer equipped with a single reflection ATR sampling module. The melting points were measured using a Thermo Scientific 9300 apparatus.

Synthesis of $[\mathrm{L}(\mathrm{Cl}) \mathrm{Ga}]_{2} \mathrm{PCl}(1) . \mathrm{LGa}(250 \mathrm{mg}, 0.513 \mathrm{mmol})$ and $\mathrm{PCl}_{3}$ (35.22 $\mathrm{mg}, 22.43 \mu \mathrm{L}, 0.256 \mathrm{mmol}$ ) were dissolved in $2 \mathrm{~mL}$ of toluene and stirred for $24 \mathrm{~h}$, during which the color of the reaction solution changed from yellow to dark orange. Storage of the solution at $-30{ }^{\circ} \mathrm{C}$ for 3 days yielded pale green solid of 1. M. p. $230{ }^{\circ} \mathrm{C}$. Yield $72.5 \mathrm{mg}(25.4 \%)$. Anal. Calcd. for $\mathrm{C}_{58} \mathrm{H}_{82} \mathrm{~N}_{4} \mathrm{Ga}_{2} \mathrm{Cl}_{3} \mathrm{P}$ : C, 62.64; $\mathrm{H}, 7.43 ; \mathrm{N}, 5.04$. Found: $\mathrm{C}, 62.6 ; \mathrm{H}$, 7.63; N, $5.33 \%$ \% ${ }^{1} \mathrm{H}$ NMR $\left(600 \mathrm{MHz}\right.$, [D8]Toluene, $\left.25^{\circ} \mathrm{C}\right): \delta 7.10-6.93(\mathrm{~m}$, $6 \mathrm{H}, \mathrm{C}_{6} \mathrm{H}_{3}-2,6-\mathrm{Pr}_{2}$ ), 4.81 (s, $1 \mathrm{H}, \gamma-\mathrm{CH}$ ), 3.55 (sept, $2 \mathrm{H},{ }^{3} \mathrm{~J}_{\mathrm{H}-\mathrm{H}}=6.7 \mathrm{~Hz}$, $\mathrm{CH}\left(\mathrm{CH}_{3}\right)_{2}$ ), 3.22 (sept, $\left.2 \mathrm{H},{ }^{3} \mathrm{~J}_{\mathrm{H}-\mathrm{H}}=6.8 \mathrm{~Hz}, \mathrm{CH}\left(\mathrm{CH}_{3}\right)_{2}\right), 1.46(\mathrm{~s}, 6 \mathrm{H}$, ArNCCH $)_{3}, 1.21\left(\mathrm{~d}, 6 \mathrm{H},{ }^{3} J_{\mathrm{H}-\mathrm{H}}=6.8 \mathrm{~Hz}, \mathrm{CH}\left(\mathrm{CH}_{3}\right)_{2}\right), 1.18\left(\mathrm{~m}, 12 \mathrm{H},{ }^{3} J_{\mathrm{H}-\mathrm{H}}=\right.$ $\left.6.6 \mathrm{~Hz}, \mathrm{CH}\left(\mathrm{CH}_{3}\right)_{2}\right), 0.98\left(\mathrm{~d}, 6 \mathrm{H},{ }^{3} \mathrm{~J}_{\mathrm{H}-\mathrm{H}}=6.8 \mathrm{~Hz}, \mathrm{CH}\left(\mathrm{CH}_{3}\right)_{2}\right) .{ }^{13} \mathrm{C} \mathrm{NMR}(150$ $\mathrm{MHz},\left[\mathrm{D}_{8}\right]$ Toluene, $\left.25^{\circ} \mathrm{C}\right): \delta 169.9\left(\mathrm{ArNCCH}_{3}\right), 145.6,143.2,142.1,127.9$, 127.5, $123.8(\mathrm{ArC}), 98.2(\gamma-\mathrm{CH}), 29.5,28.3\left(\mathrm{CH}\left(\mathrm{CH}_{3}\right)_{2}\right), 27.4,25.1,24.6$, $24.3\left(\mathrm{CH}\left(\mathrm{CH}_{3}\right)_{2}\right), 24.0\left(\mathrm{ArNCCH}_{3}\right) .{ }^{31} \mathrm{P} \mathrm{NMR}\left(242 \mathrm{MHz},\left[\mathrm{D}_{8}\right]\right.$ Toluene, $25^{\circ} \mathrm{C}$ ): 0.52. IR (neat): $v$ 3063, 2965, 2925, 2866, 1521, 1461, 1437, 1382 1314, 1254, 1177, 1099, 1018, 937, 865, 794, 757, 708, 639, 533, 474, $441,399$.

Synthesis of $[\mathrm{L}(\mathrm{Br}) \mathrm{Ga}]_{2} \mathrm{PBr}$ (2). LGa (100 mg, $\left.0.205 \mathrm{mmol}\right)$ and $\mathrm{PBr}_{3}$ $\left(27.77 \mathrm{mg}, 9.74 \mu \mathrm{L}, 0.103 \mathrm{mmol}\right.$ ) were dissolved in $0.5 \mathrm{~mL}$ of toluene- $\mathrm{d}_{8}$ in a J-Young NMR tube and stirred for $24 \mathrm{~h}$, during which the color of the reaction solution changed from yellow to dark orange. Storage of the solution at $-30{ }^{\circ} \mathrm{C}$ for 3 days yielded pale yellow crystals of 2. M. p. $222{ }^{\circ} \mathrm{C}$. Yield $48.3 \mathrm{mg}(47.1 \%)$. Anal. Calcd. for $\mathrm{C}_{58} \mathrm{H}_{82} \mathrm{~N}_{4} \mathrm{Ga}_{2} \mathrm{Br} 3 \mathrm{P}: \mathrm{C}, 55.93 ; \mathrm{H}$ 6.64; N, 4.50. Found: C, 56.10; H, 6.71; N, 4.71\%. ${ }^{1} \mathrm{H}$ NMR $(500 \mathrm{MHz}$, [D8]Toluene, $\left.25^{\circ} \mathrm{C}\right): \delta 6.98-6.91\left(\mathrm{~m}, 6 \mathrm{H}, \mathrm{C}_{6} \mathrm{H}_{3}-2,6-\mathrm{PPr}_{2}\right), 4.87(\mathrm{~s}, 1 \mathrm{H}, \gamma$ $\mathrm{CH}$ ), 3.63 (sept, $2 \mathrm{H},{ }^{3} J_{H-H}=6.8 \mathrm{~Hz}, \mathrm{CH}\left(\mathrm{CH}_{3}\right)_{2}$ ), 3.24 (sept, $2 \mathrm{H},{ }^{3} J_{H-H}=6.8$ $\left.\mathrm{Hz}, \mathrm{CH}\left(\mathrm{CH}_{3}\right)_{2}\right), 1.47\left(\mathrm{~s}, 6 \mathrm{H}, \mathrm{ArNCCH}_{3}\right), 1.25\left(\mathrm{br} \mathrm{d}, 6 \mathrm{H}^{3} \mathrm{~J}_{\mathrm{H}-\mathrm{H}}=6.5 \mathrm{~Hz}\right.$ $\left.\mathrm{CH}\left(\mathrm{CH}_{3}\right)_{2}\right), 1.20$ (br d, $\left.12 \mathrm{H},{ }^{3} \mathrm{~J}_{\mathrm{H}-\mathrm{H}}=6.8 \mathrm{~Hz}, \mathrm{CH}\left(\mathrm{CH}_{3}\right)_{2}\right), 0.96\left(\mathrm{br} \mathrm{d}, 6 \mathrm{H},{ }^{3} \mathrm{~J}_{\mathrm{H}}\right.$ $\left.H=6.8 \mathrm{~Hz}, \mathrm{CH}\left(\mathrm{CH}_{3}\right)_{2}\right) \cdot{ }^{13} \mathrm{C}$ NMR $\left(125 \mathrm{MHz}\right.$, [D8]Toluene, $\left.25^{\circ} \mathrm{C}\right): \delta 169.9$ $\left(\mathrm{ArNCCH}_{3}\right), 145.7,143.3,142.4,127.6,125.1,123.7(\mathrm{ArC}), 98.6(\gamma-\mathrm{CH})$, 29.6, $28.4\left(\mathrm{CH}\left(\mathrm{CH}_{3}\right)_{2}\right), 28.2,25.1,24.6,24.5\left(\mathrm{CH}\left(\mathrm{CH}_{3}\right)_{2}\right), 24.1\left(\mathrm{ArNCCH}_{3}\right)$. ${ }^{31} \mathrm{P}$ NMR (200 MHz, [D8]Toluene, $\left.25^{\circ} \mathrm{C}\right):-42.9$. IR (neat): v 2962, 2925, 2867, 1517, 1437, 1382, 1316, 1256, 1176, 1099, 1017, 935, 863, 797 $757,639,531,450,388$

Synthesis of $[\mathrm{L}(\mathrm{Cl}) \mathrm{Ga}]_{2} \mathrm{As}_{2}$ (3). $\mathrm{LGa}(100 \mathrm{mg}, 0.205 \mathrm{mmol})$ and $\mathrm{AsCl}_{3}$ (18.67 mg, $8.64 \mu \mathrm{L}, 0.103 \mathrm{mmol}$ ) were dissolved in $0.5 \mathrm{~mL}$ of toluene-d $\mathrm{d}_{8}$ in a J-Young NMR tube and stirred for $24 \mathrm{~h}$. During this period, the color of the reaction solution changed from yellow to reddish brown. The solution was kept at $0{ }^{\circ} \mathrm{C}$ for 1 day to yield green crystals of 3. M. p. $255^{\circ} \mathrm{C}$ (dec.). Yield $12.8 \mathrm{mg}(10.7 \%)$. Anal. Calcd. for $\mathrm{C}_{58} \mathrm{H}_{82} \mathrm{~N}_{4} \mathrm{Cl}_{2} \mathrm{Ga}_{2} \mathrm{As}_{2}$ : C, 58.27; $\mathrm{H}$, 6.91; N, 4.69. Found: C, 58.12; H, 6.85; N, $4.55 \%$. ${ }^{1} \mathrm{H}$ NMR $(500 \mathrm{MHz}$, $\left[\mathrm{D}_{8}\right]$ Toluene, $\left.25^{\circ} \mathrm{C}\right): \delta 7.08-6.89\left(\mathrm{~m}, 6 \mathrm{H}, \mathrm{C}_{6} \mathrm{H}_{3}-2,6-\mathrm{Pr}_{2}\right), 4.85(\mathrm{~s}, 1 \mathrm{H}, \gamma-\mathrm{CH})$ 3.77 (sept, $\left.2 \mathrm{H},{ }^{3} \mathrm{~J}_{\mathrm{H}-\mathrm{H}}=6.8 \mathrm{~Hz}, \mathrm{CH}\left(\mathrm{CH}_{3}\right)_{2}\right), 2.90$ (sept, $2 \mathrm{H},{ }^{3} \mathrm{~J}_{\mathrm{H}-\mathrm{H}}=6.8 \mathrm{~Hz}$, $\left.\mathrm{CH}\left(\mathrm{CH}_{3}\right)_{2}\right), 1.61\left(\mathrm{~s}, 6 \mathrm{H}, \mathrm{ArNCCH}_{3}\right), 1.35\left(\mathrm{~d}, 6 \mathrm{H},{ }^{3} \mathrm{~J}_{\mathrm{H}-\mathrm{H}}=6.7 \mathrm{~Hz}, \mathrm{CH}\left(\mathrm{CH}_{3}\right)_{2}\right)$, $1.24\left(\mathrm{~d}, 6 \mathrm{H},{ }^{3} \mathrm{~J}_{\mathrm{H}-\mathrm{H}}=6.9 \mathrm{~Hz}, \mathrm{CH}\left(\mathrm{CH}_{3}\right)_{2}\right), 1.09\left(\mathrm{~d}, 6 \mathrm{H},{ }^{3} \mathrm{~J}_{\mathrm{H}-\mathrm{H}}=6.9 \mathrm{~Hz}\right.$, $\left.\mathrm{CH}\left(\mathrm{CH}_{3}\right)_{2}\right), 0.97\left(\mathrm{~d}, 6 \mathrm{H},{ }^{3} \mathrm{~J}_{\mathrm{H}-\mathrm{H}}=6.9 \mathrm{~Hz}, \mathrm{CH}\left(\mathrm{CH}_{3}\right)_{2}\right) .{ }^{13} \mathrm{C} \mathrm{NMR}(125 \mathrm{MHz}$, $\left[\mathrm{D}_{8}\right]$ Toluene, $\left.25^{\circ} \mathrm{C}\right): \delta 169.1\left(\mathrm{ArNCCH}_{3}\right), 145.8,142.7,140.7,127.4,124.7$
124.1 (ArC), $97.3(\gamma-\mathrm{CH}), 29.7,28.0\left(\mathrm{CH}\left(\mathrm{CH}_{3}\right)_{2}\right), 27.2,24.8,24.7,23.9$ $\left(\mathrm{CH}\left(\mathrm{CH}_{3}\right)_{2}\right), 23.6\left(\mathrm{ArNCCH}_{3}\right)$. IR (neat): v 3064, 2966, 2862, 1556, 1521, $1461,1437,1382,1359,1312,1260,1174,1100,1054,1016,935,865$, $790,753,711,635,526,440$

Synthesis of [L(Cl)Ga]As ${ }_{2}\left[\mathrm{Ga}\left(\mathrm{NMe}_{2}\right) \mathrm{L}\right]$ (4). A solution of $\mathrm{LGa}(100 \mathrm{mg}$, $0.205 \mathrm{mmol}$ ) and $\mathrm{Me}_{2} \mathrm{NAsCl}_{2}(19.56 \mathrm{mg}, 10.62 \mu \mathrm{L}, 0.103 \mathrm{mmol}$ ) were dissolved in $0.5 \mathrm{~mL}$ of toluene- $\mathrm{d}_{8}$ in a J-Young NMR tube and stirred for $24 \mathrm{~h}$ at $80^{\circ} \mathrm{C}$. The color of the reaction solution changed from yellow to red and a red solid precipitated, which was isolated by filtration and recrystallized in toluene, yielding reddish brown crystals of 4 . M. p. $239^{\circ} \mathrm{C}$ Yield $43.2 \mathrm{mg}\left(34.8 \%\right.$ ). Anal. Calcd. for $\mathrm{C}_{60} \mathrm{H}_{88} \mathrm{~N}_{5} \mathrm{Ga}_{2} \mathrm{As}{ }_{2} \mathrm{Cl}$ : C, 59.85; $\mathrm{H}$, 7.37; N, 5.82. Found: C, 60.06; $\mathrm{H}, 7.40 ; \mathrm{N}, 6.04 \% .{ }^{1} \mathrm{H} \mathrm{NMR}(600 \mathrm{MHz}$ $\left[\mathrm{D}_{8}\right]$ Toluene, $\left.25^{\circ} \mathrm{C}\right): \delta 7.11-6.86\left(\mathrm{~m}, 12 \mathrm{H}, \mathrm{C}_{6} \mathrm{H}_{3}-2,6-\mathrm{Pr}_{2}\right), 4.87(\mathrm{~s}, 1 \mathrm{H}, \gamma$ $\mathrm{CH}), 4.72(\mathrm{~s}, 1 \mathrm{H}, \gamma-\mathrm{CH}), 3.77\left(\mathrm{sept},{ }^{3} \mathrm{~J}_{\mathrm{H}-\mathrm{H}}=6.8 \mathrm{~Hz}, 2 \mathrm{H}, \mathrm{CH}\left(\mathrm{CH}_{3}\right)_{2}\right), 3.54$ (sept, $\left.{ }^{3} J_{H-H}=6.8 \mathrm{~Hz}, 2 \mathrm{H}, \mathrm{CH}\left(\mathrm{CH}_{3}\right)_{2}\right), 3.17$ (sept, ${ }^{3} J_{H-H}=6.8 \mathrm{~Hz}, 2 \mathrm{H}$, $\left.\mathrm{CH}\left(\mathrm{CH}_{3}\right)_{2}\right), 2.95$ (br s, $\left.3 \mathrm{H}, \mathrm{N}\left(\mathrm{CH}_{3}\right)_{2}\right), 2.77$ (sept, ${ }^{3} \mathrm{~J}_{\mathrm{H}-\mathrm{H}}=6.8 \mathrm{~Hz}, 2 \mathrm{H}$ $\left.\mathrm{CH}\left(\mathrm{CH}_{3}\right)_{2}\right), 2.37$ (br s, $\left.3 \mathrm{H}, \mathrm{N}\left(\mathrm{CH}_{3}\right)_{2}\right), 1.63\left(\mathrm{~s}, 6 \mathrm{H}, \mathrm{ArNCCH}_{3}\right), 1.60(\mathrm{~s}, 6 \mathrm{H}$, ArNCCH $)_{3}, 1.31\left(\mathrm{~m}, 18 \mathrm{H}, 3^{3} \mathrm{~J}_{\mathrm{H}-\mathrm{H}}=6.8 \mathrm{~Hz}, \mathrm{CH}\left(\mathrm{CH}_{3}\right)_{2}\right), 1.21\left(\mathrm{~d}, 6 \mathrm{H}, 3^{3} \mathrm{~J}_{\mathrm{H}-\mathrm{H}}=\right.$ $\left.6.8 \mathrm{~Hz}, \mathrm{CH}\left(\mathrm{CH}_{3}\right)_{2}\right), 1.13\left(\mathrm{~d}, 6 \mathrm{H},{ }^{3} \mathrm{~J}_{\mathrm{H}-\mathrm{H}}=6.8 \mathrm{~Hz}, \mathrm{CH}\left(\mathrm{CH}_{3}\right)_{2}\right), 1.02(\mathrm{~d}, 6 \mathrm{H}$, $\left.{ }^{3} J_{\mathrm{H}-\mathrm{H}}=6.8 \mathrm{~Hz}, \mathrm{CH}\left(\mathrm{CH}_{3}\right)_{2}\right), 0.98\left(\mathrm{~d}, 6 \mathrm{H},{ }^{3} \mathrm{~J}_{\mathrm{H}-\mathrm{H}}=6.8 \mathrm{~Hz}, \mathrm{CH}\left(\mathrm{CH}_{3}\right)_{2}\right), 0.97(\mathrm{~d}$, $\left.6 \mathrm{H},{ }^{3} \mathrm{~J}_{\mathrm{H}-\mathrm{H}}=6.8 \mathrm{~Hz}, \mathrm{CH}\left(\mathrm{CH}_{3}\right)_{2}\right) .{ }^{13} \mathrm{C}$ NMR $\left(150 \mathrm{MHz},\left[\mathrm{D}_{8}\right]\right.$ Toluene, $\left.25^{\circ} \mathrm{C}\right)$ : $\delta$ 169.0, $168.4\left(\mathrm{ArNCCH}_{3}\right), 146.0,145.1,142.9,142.5,142.4,141.3,127.1$ 127.0, 125.1, 124.5, 124.4, $123.7(\operatorname{ArC}), 97.3,96.3(\gamma-\mathrm{CH}), 44.8,44.2$ $\left(\mathrm{N}\left(\mathrm{CH}_{3}\right)_{2}\right), 29.7,29.2,28.1,28.0\left(\mathrm{CH}\left(\mathrm{CH}_{3}\right)_{2}\right), 27.0,25.8,25.1,24.8,24.7$ 24.5, $24.1\left(\mathrm{CH}\left(\mathrm{CH}_{3}\right)_{2}\right), 23.7,23.6\left(\mathrm{ArNCCH}_{3}\right)$. IR (neat): v 2965, 2866, 2754, 1549, 1520, 1434, 1386, 1314, 1256, 1175, 1100, 1018, 975, 937, $856,792,754,634,546,523,856,438 \mathrm{~cm}^{-1}$.

Synthesis of $\left[\left(\mathrm{L}\left(\mathrm{Me}_{2} \mathrm{~N}\right) \mathrm{Ga}_{2} \mathrm{As}_{2}\right.\right.$ (5). LGa (132 $\left.\mathrm{mg}, 0.272 \mathrm{mmol}\right)$ and $\mathrm{As}\left(\mathrm{NMe}_{2}\right)_{3}(28.12 \mathrm{mg}, 25.00 \mu \mathrm{L}, 0.136 \mathrm{mmol})$ were dissolved in $1.5 \mathrm{~mL}$ of mesitylene. The solution was stirred for 5 days at $165^{\circ} \mathrm{C}$. The color of the reaction solution changed from yellow to red and a red solid precipitated, which was isolated by filtration and washed with hexane, yielding a reddish orange solid of 5. M. p. $248{ }^{\circ} \mathrm{C}$ (dec.). Yield $21.8 \mathrm{mg}$ (13.3\%). Anal. Calcd. for $\mathrm{C}_{62} \mathrm{H}_{94} \mathrm{~N}_{6} \mathrm{Ga}_{2} \mathrm{As}_{2}$ : C, 61.40; $\mathrm{H}, 7.81 ; \mathrm{N}, 6.93$. Found: $\mathrm{C}, 61.27 ; \mathrm{H}, 7.82$ $\mathrm{N}, 6.89$ \%. IR (neat): v 3060, 2958, 2923, 2866, 2758, 1589, 1521, 1460 , 1438, 1383, 1317, 1257, 1174, 1099, 1056, 1017, 975, 934, 885, 794, 757, $639,600,497,478,447 \mathrm{~cm}^{-1}$

Synthesis of $\left[\mathrm{L}\left(\mathrm{Me}_{2} \mathbf{N}\right) \mathbf{A l}_{2} \mathbf{A s}_{2}\right.$ (6). LAl $(30 \mathrm{mg}, 0.068 \mathrm{mmol})$ and $\mathrm{As}\left(\mathrm{NMe}_{2}\right)_{3}(6.98 \mathrm{mg}, 6.21 \mu \mathrm{L} 0.034 \mathrm{mmol})$ were dissolved in $0.5 \mathrm{~mL}$ of toluene- $\mathrm{d}_{8}$ in a J-Young NMR tube and stirred for $4 \mathrm{~h}$ at $80{ }^{\circ} \mathrm{C}$. The color of the reaction solution changed from red to reddish brown. The solution was kept at room temperature for further 3 days to yield pale yellow crystals of 6. M. p. $275{ }^{\circ} \mathrm{C}$. Yield $13 \mathrm{mg}$ (35.6\%). Anal. Calcd. for $\mathrm{C}_{62} \mathrm{H}_{94} \mathrm{~N}_{6} \mathrm{Al}_{2} \mathrm{As}_{2}$ : C, 66.06; $\mathrm{H}, 8.41 ; \mathrm{N}, 7.46$. Found: $\mathrm{C}, 65.88 ; \mathrm{H}, 8.34 ; \mathrm{N}$, $7.51 \% .{ }^{1} \mathrm{H}$ NMR $\left(500 \mathrm{MHz},\left[\mathrm{D}_{8}\right]\right.$ Toluene, $\left.25{ }^{\circ} \mathrm{C}\right): \delta 7.12-6.94(\mathrm{~m}, 6 \mathrm{H}$, $\mathrm{C}_{6} \mathrm{H}_{3}-2,6-i \mathrm{Pr}_{2}$ ), $4.92(\mathrm{~s}, 1 \mathrm{H}, \gamma-\mathrm{CH}), 3.53$ (sept, ${ }^{3} \mathrm{~J}_{\mathrm{H}-\mathrm{H}}=6.8 \mathrm{~Hz}, 2 \mathrm{H}$, $\mathrm{CH}\left(\mathrm{CH}_{3}\right)_{2}$ ), 2.93 (sept, $\left.{ }^{3} \mathrm{~J}_{\mathrm{H}-\mathrm{H}}=6.8 \mathrm{~Hz}, 2 \mathrm{H}, \mathrm{CH}\left(\mathrm{CH}_{3}\right)_{2}\right), 2.69(\mathrm{~s}, 3 \mathrm{H}$, $\left.\mathrm{N}\left(\mathrm{CH}_{3}\right)_{2}\right), 2.36\left(\mathrm{~s}, 3 \mathrm{H}, \mathrm{N}\left(\mathrm{CH}_{3}\right)_{2}\right), 1.61(\mathrm{~s}, 6 \mathrm{H}, \operatorname{ArNCCH})_{3}, 1.28(\mathrm{~m}, 12 \mathrm{H}$, $\left.\mathrm{CH}\left(\mathrm{CH}_{3}\right)_{2}\right), 0.99\left(\mathrm{~d}, 6 \mathrm{H}, 3^{3} \mathrm{~J}_{\mathrm{H}-\mathrm{H}}=6.8 \mathrm{~Hz}, \mathrm{CH}\left(\mathrm{CH}_{3}\right)_{2}\right), 0.96\left(\mathrm{~d}, 6 \mathrm{H},{ }^{3} \mathrm{~J}_{\mathrm{H}-\mathrm{H}}=\right.$ $\left.6.8 \mathrm{~Hz}, \mathrm{CH}\left(\mathrm{CH}_{3}\right)_{2}\right) .{ }^{13} \mathrm{C}$ NMR $\left(150 \mathrm{MHz}\right.$, [D 8 ]Toluene, $\left.25^{\circ} \mathrm{C}\right): \delta 169.4$ $\left(\mathrm{ArNCCH}_{3}\right), 145.4,143.2,142.1,126.9,124.4,124.2(\mathrm{ArC}), 98.0(\gamma-\mathrm{CH})$, 44.2, $42.5\left(\mathrm{~N}\left(\mathrm{CH}_{3}\right)_{2}\right), 29.2,28.1\left(\mathrm{CH}\left(\mathrm{CH}_{3}\right)_{2}\right), 25.8,25.2,24.8,24.7$ $\left(\mathrm{CH}\left(\mathrm{CH}_{3}\right)_{2}\right), 23.7\left(\mathrm{ArNCCH}_{3}\right)$. IR (neat): $v$ 2962, 2866, 2758, 1622, 1521, 1435, 1389, 1314, 1257, 1166, 1092, 1014, 980, 935, 865, 790, 758, 711, $642,619,544,524,428 \mathrm{~cm}^{-1}$

Synthesis of $\left[\mathrm{L}\left(\mathrm{Et}_{2} \mathrm{~N}\right) \mathrm{Ga}_{2} \mathrm{Bi}_{2}(7) . \mathrm{Bi}\left(\mathrm{NEt}_{2}\right)_{3}(0.066 \mathrm{~g}, 45 \mu \mathrm{L}, 0.15 \mathrm{mmol})\right.$ was added to a solution of LGa $(0.15 \mathrm{~g}, 0.30 \mathrm{mmol})$ in $3 \mathrm{~mL}$ of toluene at ambient temperature. The solution was stirred for 4 days, during which the color changed from yellow to purple. Storage of the solution at ambient temperature for 2 days resulted in the formation of purple crystals of $\mathbf{7}$, 
which were washed with hexane $(2 \times 1 \mathrm{~mL})$ to afford 7 in a pure form. M. p. $120{ }^{\circ} \mathrm{C}$ (dec.). Yield $0.083 \mathrm{~g}$ (65\%). Anal. Calcd. for $\mathrm{C}_{66} \mathrm{H}_{102} \mathrm{Bi}_{2} \mathrm{Ga}_{2} \mathrm{~N}_{6}$ : $\mathrm{C}$, 51.58; H, 6.69; N, 5.47. Found: C, 51.76; H, 6.61; N, $5.42 \%$. ${ }^{1} \mathrm{H}$ NMR (600 $\mathrm{MHz}$, [D6]Benzene, $\left.25^{\circ} \mathrm{C}\right): \delta 7.11(\mathrm{~m}, 6 \mathrm{H}, \mathrm{ArH}), 7.00(\mathrm{~m}, 6 \mathrm{H}, \mathrm{ArH}), 4.74$ (s, $2 \mathrm{H}, \gamma-\mathrm{CH}$ ), 4.07 (sept, $\left.{ }^{3} \mathrm{JHH}_{\mathrm{H}}=6.8 \mathrm{~Hz}, 4 \mathrm{H}, \mathrm{CH}\left(\mathrm{CH}_{3}\right)_{2}\right), 3.72\left(\mathrm{q},{ }^{3} \mathrm{JHH}=\right.$ $6.9 \mathrm{~Hz}, 4 \mathrm{H}, \mathrm{NCH}_{2} \mathrm{CH}_{3}$ ), 2.80 (q, ${ }^{3} \mathrm{JHH}=6.9 \mathrm{~Hz}, 4 \mathrm{H}, \mathrm{NCH}_{2} \mathrm{CH}_{3}$ ), 2.77 (sept, $\left.{ }^{3} \mathrm{~J}_{\mathrm{HH}}=6.8 \mathrm{~Hz}, 4 \mathrm{H}, \mathrm{CH}\left(\mathrm{CH}_{3}\right)_{2}\right), 1.58\left(\mathrm{~s}, 12 \mathrm{H}, \mathrm{ArNCCH}_{3}\right), 1.39\left(\mathrm{~d},{ }^{3} \mathrm{JHH}_{\mathrm{HH}}=\right.$ $\left.6.8 \mathrm{~Hz}, 12 \mathrm{H}, \mathrm{CH}\left(\mathrm{CH}_{3}\right)_{2}\right), 1.36\left(\mathrm{t},{ }^{3} \mathrm{JHH}_{\mathrm{HH}}=6.9 \mathrm{~Hz}, 6 \mathrm{H}, \mathrm{NCH}_{2} \mathrm{CH}_{3}\right), 1.29(\mathrm{~d}$, $\left.{ }^{3} \mathrm{~J}_{\mathrm{HH}}=6.8 \mathrm{~Hz}, 12 \mathrm{H}, \mathrm{CH}\left(\mathrm{CH}_{3}\right)_{2}\right), 1.11\left(\mathrm{~d},{ }^{3} \mathrm{~J}_{\mathrm{HH}}=6.8 \mathrm{~Hz}, 12 \mathrm{H}, \mathrm{CH}\left(\mathrm{CH}_{3}\right)_{2}\right)$, $1.05\left(\mathrm{~d},{ }^{3} \mathrm{JHH}_{\mathrm{H}}=6.8 \mathrm{~Hz}, 12 \mathrm{H}, \mathrm{CH}\left(\mathrm{CH}_{3}\right)_{2}\right), 1.02\left(\mathrm{br} \mathrm{s}, 6 \mathrm{H}, \mathrm{NCH}_{2} \mathrm{CH}_{3}\right) .{ }^{33} \mathrm{C}$ NMR $\left(150 \mathrm{MHz},\left[\mathrm{D}_{6}\right]\right.$ Benzene, $\left.25^{\circ} \mathrm{C}\right) . \delta 169.1\left(\mathrm{ArNCCH}_{3}\right), 145.7,143.7$, 143.4, 143.4, 127.0, 125.4, $124.6(\mathrm{ArC}), 98.3(\gamma \mathrm{CH}), 48.1,46.4$ $\left(\mathrm{NCH}_{2} \mathrm{CH}_{3}\right), 29.3,27.5,\left(\mathrm{CH}\left(\mathrm{CH}_{3}\right)_{2}\right), 27.1\left(\mathrm{CH}\left(\mathrm{CH}_{3}\right)_{2}\right), 25.6(\mathrm{ArNCCH})_{3}$, $24.8\left(\mathrm{CH}\left(\mathrm{CH}_{3}\right)_{2}\right), 17.9,16.4\left(\mathrm{NCH}_{2} \mathrm{CH}_{3}\right)$. IR (neat): v 2962, 2923, 2864 , $2818,1543,1517,1461,1438,1383,1313,1254,1168,1104,1057,1008$, $935,876,853,793,757,719,625,593,559,530,456,438 \mathrm{~cm}^{-1}$.

Computational details. The geometric parameters of the species under study were fully optimized in the gas phase at the BP86-D3/def2-SVP theoretical level[27-30] with a corresponding small-core relativistic effective core potential for $\mathrm{Sb}$ and $\mathrm{Bi}^{[31]}$ employing ultrafine grid. The stationary points were characterized as minima on the potential energy surface by vibrational analysis (the number of imaginary frequencies (NImag) was equal to zero) and the structures obtained were used for the subsequent calculations. $\mathrm{AIM}^{[32]}$ and $\mathrm{ELF}^{[33,34]}$ computations were performed with DGrid program ${ }^{[42]}$ using densities from the all-electron scalar relativistic (SR) ZORA-BP86-D3/TZP computations. ${ }^{[27-29,43]}$ ELF basin populations were calculated for a rectangular parallelepipedic grid with a mesh size of $0.1 \mathrm{bohr}$. The energies of frontier molecular orbitals were calculated at the $\omega B$ 97X-D/def2-SVP level of theory. ${ }^{[44]} \mathrm{NBO}$ analysis ${ }^{[35]}$ was performed at the BP86-D3/def2-SVP theoretical level as implemented in Gaussian09. ${ }^{[45]}$ SR-ZORA-BP86-D3/TZP computations were performed using ADF2013 suite of programs (core potentials were not used, and quality of the Becke numerical integration grid was set to the keyword good), ${ }^{[46-48]}$ while the remaining computations were carried out in Gaussian09 code. ${ }^{[45]}$ Detailed information about AIM, ELF, and NBO can be found elsewhere. ${ }^{[32-35]}$

Single-crystal X-ray analyses. The crystals were mounted on nylon loops $\left(2 \cdot 2 \mathrm{C}_{7} \mathrm{H}_{8}, \mathbf{3}, \mathbf{4}, \mathbf{6}\right)$ and a glass fiber $(\mathbf{7})$ in inert oil. Data were collected using a Bruker AXS D8 Kappa diffractometer with APEX2 detector (monochromated Mo $\kappa_{\alpha}$ radiation, $\lambda=0.71073 \AA$ ) at $100(2) \mathrm{K}\left(2 \cdot 2 \mathbf{C}_{7} \mathbf{H}_{8}, \mathbf{3}, \mathbf{6}\right)$ and $170(2) \mathrm{K}(4)$ and a STOE IPDS II (mono-chromated Mo $\kappa_{\alpha}$ radiation, $\lambda=$ $0.71073 \AA)$ at $173(2) \mathrm{K}(\mathbf{7}) \cdot \mathbf{2} \cdot 2 \mathrm{C}_{7} \mathrm{H}_{8}:\left[\mathrm{C}_{72} \mathrm{H}_{98} \mathrm{Br}_{3} \mathrm{Ga}_{2} \mathrm{~N}_{4} \mathrm{P} \cdot 2 \mathrm{C}_{7} \mathrm{H}_{8}\right], M=$ 1429.68, pale yellow crystal, $(0.390 \times 0.329 \times 0.160 \mathrm{~mm})$; monoclinic, space group $P 2{ }_{1} / c ; a=14.1855(7) \AA, b=20.0810(9) \AA, c=24.7875(12)$ $\AA ; \alpha=90^{\circ}, \beta=99.843(3)^{\circ}, \gamma=90^{\circ}, V=6957.0(6) \AA^{3} ; Z=4 ; \mu=2.563 \mathrm{~mm}$ 1; $\rho_{\text {calc }}=1.365 \mathrm{~g} \cdot \mathrm{cm}^{-3} ; 176583$ reflections $\left(\theta_{\max }=33.295^{\circ}\right), 26734$ unique $\left(R_{\text {int }}=0.0425\right)$; 955 parameters; largest max./min in the final difference Fourier synthesis $2.178 \mathrm{e} \cdot \AA^{-3 /}-1.654 \mathrm{e} \cdot \AA^{-3}$; max./min. transmission $0.61 / 0.30 ; \quad R_{1}=0.0571(I>2 \sigma(I)), w R_{2}=0.1386$ (all data). 3: $\left[\mathrm{C}_{58} \mathrm{H}_{82} \mathrm{As}_{2} \mathrm{Cl}_{2} \mathrm{Ga}_{2} \mathrm{~N}_{4}\right], M=1195.45$, greenish yellow crystal, $(0.116 \times 0.050$ $\times 0.046 \mathrm{~mm}$ ); monoclinic, space group $P 21 / n ; a=13.6550(16) \AA, b=$ 13.9479(15) $\AA, c=15.7645(19) \AA ; \alpha=90^{\circ}, \beta=105.410(4)^{\circ}, y=90^{\circ}, V=$ 2894.5(6) $\AA^{3} ; Z=2 ; \mu=2.197 \mathrm{~mm}^{-1} ; \rho_{\text {calc }}=1.372 \mathrm{~g} \mathrm{~cm}^{-3} ; 34154$ reflections $\left(\theta_{\max }=30.503^{\circ}\right), 8734$ unique $\left(R_{\text {int }}=0.0512\right) ; 317$ parameters; largest max./min in the final difference Fourier synthesis 0.589 e $\cdot \AA^{-3} /-0.737$ e $\cdot \AA$ 3; max. $/ \mathrm{min}$. transmission 0.75/0.70; $R_{1}=0.0489(\mathrm{I}>2 \sigma(\mathrm{I})), w R_{2}=0.0965$ (all data). 4: $\left[\mathrm{C}_{60} \mathrm{H}_{88} \mathrm{As}_{2} \mathrm{ClGa}_{2} \mathrm{~N}_{5}\right], M=1204.08$, brownish orange crystal, $(0.200 \times 0.200 \times 0.100 \mathrm{~mm})$; triclinic, space group $P-1 ; a=10.7219(8) \AA$, $b=12.2486(8) \AA, c=13.2240(9) \AA ; \alpha=93.277(6)^{\circ}, \beta=107.628(6)^{\circ}, y=$ 108.982(6),$V=1541.6(2) A^{3} ; Z=1 ; \mu=2.021 \mathrm{~mm}^{-1} ; \rho_{\text {calc }}=1.297 \mathrm{~g} \cdot \mathrm{cm}^{-}$ 3; 14495 reflections $\left(\theta_{\max }=26.369^{\circ}\right), 6281$ unique $\left(R_{\text {int }}=0.0475\right) ; 347$ parameters; largest max./min in the final difference Fourier synthesis 0.648 e $\cdot \AA^{-3 /} /-0.477$ e $\cdot \AA^{-3} ;$ max./min. transmission $1.00000 / 0.89851 ; R_{1}=$
$0.0465(\mathrm{I}>2 \sigma(\mathrm{I})), w R_{2}=0.1173$ (all data). $6: \cdot\left[\mathrm{C}_{62} \mathrm{H}_{94} \mathrm{Al}_{2} \mathrm{As}_{2} \mathrm{~N}_{6}\right], \quad M=$ 1127.23, pale yellow crystal, $(0.401 \times 0.327 \times 0.040 \mathrm{~mm})$; triclinic, space group $P-1 ; a=10.7453(7) \AA, b=15.6155(10) \AA, c=18.2991(12) \AA ; a=$ $84.315(3)^{\circ}, \beta=89.408(3)^{\circ}, \gamma=79.142(3)^{\circ}, V=3000.6(3) \AA^{3} ; Z=2 ; \mu=$ $1.186 \mathrm{~mm}^{-1} ; \rho_{\text {calc }}=1.248 \mathrm{~g} \cdot \mathrm{cm}^{-3} ; 72834$ reflections $\left(\theta_{\max }=30.694^{\circ}\right), 18296$ unique $\left(R_{\text {int }}=0.0426\right) ; 673$ parameters; largest max./min in the final difference Fourier synthesis $1.581 \mathrm{e} \cdot \AA^{-3} /-0.874 \mathrm{e} \cdot \AA^{-3}$; max./min. transmission 0.75/0.58; $R_{1}=0.0473(\mathrm{I}>2 \sigma(\mathrm{I})), w R_{2}=0.1432$ (all data). 7 [ $\left.\mathrm{C}_{66} \mathrm{H}_{102} \mathrm{Bi}_{2} \mathrm{Ga}_{2} \mathrm{~N}_{6}\right], M=1536.93$, red crystal, $(0.250 \times 0.150 \times 0.120 \mathrm{~mm})$; monoclinic, space group $P 21 / n ; a=11.4654$ (3) $A, b=14.0433$ (3) $\AA, c=$ 20.8486(4) $\AA ; \alpha=90^{\circ}, \beta=90.352(2)^{\circ}, \gamma=90^{\circ}, V=3356.81(13) \AA^{3} ; Z=2$; $\mu=6.062 \mathrm{~mm}^{-1} ; \rho_{\text {calc }}=1.521 \mathrm{~g} \cdot \mathrm{cm}^{-3} ; 51838$ reflections $\left(\theta_{\max }=26.000^{\circ}\right)$ 6597 unique $\left(R_{\text {int }}=0.0856\right)$; 375 parameters; largest max. $/ \mathrm{min}$ in the final difference Fourier synthesis $1.004 \mathrm{e} \cdot \AA^{-3 /}-1.223 \mathrm{e} \cdot \AA^{-3}$; max./min transmission $0.274 / 0.184 ; R_{1}=0.0499(\mathrm{I}>2 \sigma(\mathrm{I})), w R_{2}=0.0859$ (all data). The structures were solved by Direct Methods (SHELXS-97) ${ }^{[49]}$ and refined anisotropically by full-matrix least-squares on $F^{2}$ (SHELXL-2014). ${ }^{[50]}$ Absorption corrections were performed semi-empirically from equivalent reflections on basis of multi-scans $(\mathbf{4}, \mathbf{6}, \mathbf{7})$ or numerical from indexed faces $\left(2 \cdot 2 \mathrm{C}_{7} \mathrm{H}_{8}\right)(\mathrm{SABABS}, \mathrm{XPREP})$. Hydrogen atoms were refined using a riding model or rigid methyl groups. In 2 the central $\mathrm{P}-\mathrm{Br}$ group is disordered over three position. The $\mathrm{P}-\mathrm{Br}$ distances were restrained to be equal (SADI) and RIGU restraints were applied to the ADP. The $P$ atom of the smallest component could only be refined isotropically. An iso-propyl group is disordered over two position. The bond lengths of corresponding bonds were restrained to be equal and RIGU, SIMU and DELU restraints were applied to the ADP of the $C$ atoms. The structure also contains two toluene molecules, which are disordered over two positions each. The fragments were fitted with DSR ${ }^{[51]}$ and SADI restraints were use for the 1,2 and 1,3 distances. The $\mathrm{C}-\mathrm{C}$ bond of the methyl group was restrained to be $1.51 \AA$ (DFIX) and the entire molecules were restrained to planarity (FLAT). SIMU and RIGU restraints were applied to the ADP. In 4 the molecule is disordered over a center of inversion. A refinement in $\mathrm{P} 1$ resolves the disorder but leads to serious problems with correlations and unrealistic values of the bonding parameter of the $\mathrm{NMe}_{2}$ residue. RIGU restraints were applied to the ADP of the $\mathrm{NMe}_{2}$ group. One of the ethyl groups of the diethylamido ligand of $\mathbf{7}$ is disordered. Appropriate distance and anisotropic displacement restraints were used for this fragment.

The crystallographic data of $\mathbf{2} \cdot 2 \mathrm{C}_{7} \mathrm{H}_{8}, \mathbf{3}, \mathbf{4}, \mathbf{6}$ and $\mathbf{7}$ (excluding structure factors) have been deposited with the Cambridge Crystallographic Data Centre as supplementary publication nos. CCDC-1579373 (2), CCDC1583617 (3), CCDC-1579371 (4), CCDC-1579372 (6) and CCDC-579351 (7). Copies of the data can be obtained free of charge from The Cambridge Crystallographic Data Centre via www.ccdc.cam.ac.uk/data request/cif.

\section{Acknowledgements}

St.S. acknowledges financial support by the Deutsche Forschungsgemeinschaft DFG (SCHU 1069/22-1) and A.S.N. is thankful to the Siberian Supercomputer Center SB RAS for providing computational resources. Dr. K. Merz (Ruhr University Bochum) and E. Hammes (University of Düsseldorf) are acknowledged for data collection (XRD) of compounds 2 and 7.

Keywords: Main group elements • Subvalent compounds • Bond activation reaction

[1] Reviews: a) C. Jones, A. Stasch In The Group 13 Metals Aluminium, Gallium, Indium and Thallium: Chemical Patterns and Peculiarities, Chapter 5, Eds. S. Aldridge, A. J. Downs, 2011, John Wiley \& Sons; b) 
Y.-C. Tsai, Coord. Chem. Rev. 2012, 256, 722-758; c) M. Asay, C. Jones, M. Driess, Chem. Rev. 2011, 111, 354-396; d) S. Nagendran, H. W. Roesky, Organometallics 2008, 27, 457-492; e) R. J. Baker, C. Jones, Coord. Chem. Rev. 2005, 249, 1857-1869; f) S. Gonzalez-Gallardo, G Prabusankar, T. Cadenbach, C. Gemel, M. von Hopffgarten, G. Frenking R. A. Fischer, Struct. Bonding (Berlin) 2010, 136, 147-188.

[2] N. J. Hardman, P. P. Power, ACS Symp. Ser. 2002, 822, 2-15

[3] H. W. Roesky, In Inorganic Chemistry in Focus II; Eds. G. Meyer, D. Naumann, L. Wesemann, Wiley-VCH, Weinheim, Germany, 2005, pp 89-103.

[4] T. Chu, I. Korobkov, G. I. Nikonov, J. Am. Chem. Soc. 2014, 136, 91959202

[5] a) T. Chu, Y. Boyko, I. Korobkov, G. I. Nikonov, Organometallics $\mathbf{2 0 1 5}$ 34, 5363-5365; b) M. R. Crimmin, M. J. Butler, A. J. P. White, Chem. Commun. 2015, 51, 15994-15996; c) L. Kong, R. Ganguly, Y. Li, R. Kinjo Chem. Eur. J. 2016, 22,1922-1925.

[6] a) N. Hardman, R. J. Wright, A. D. Philips, P. P. Power, J. Am. Chem. Soc. 2003, 125, 2667-2679; b) A. Kempter, C. Gemel, N.J. Hardman, R. A. Fischer, Inorg. Chem. 2006, 45, 3133-3138; c) A. Kempter, C. Gemel R. A. Fischer, Chem. Commun. 2006, 1551-1553; d) A. Kempter, C. Gemel, T. Cadenbach, R. A. Fischer, Organometallics 2007, 26, 42574264; e) A. Kempter, C. Gemel, R. A. Fischer, Chem. Eur. J. 2007, 13 2990-3000.

[7] a) A. Seifert, D. Scheid, G. Linti, T. Zessin, Chem. Eur. J. 2009, 15 12114-12120; b) E. Herappe-Mejía, K. Trujillo-Hernández, J. Carlos Garduño-Jiménez, F. Cortés-Guzmán, D. Martínez-Otero, V. Jancik, Dalton Trans. 2015, 44, 16894-16902.

[8] A. Kempter, C. Gemel, R. A. Fischer, Inorg. Chem. 2008, 47, 7279-7285.

[9] G. Prabusankar, C. Gemel, M. Winter, R. W. Seidel, R. A. Fischer, Chem. Eur. J. 2010, 16, 6041-6047.

[10] G. Prabusankar, A. Kempter, C. Gemel, M.-K. Schröter, R. A. Fischer, Angew. Chem. 2008, 120, 7344-7347; Angew. Chem. Int. Ed. 2008, 47 7234-7237.

[11] G. Prabusankar, C. Gemel, P. Parameswaran, C. Flener, G. Frenking. R. A. Fischer, Angew. Chem. 2009, 121, 5634-5637; Angew. Chem. Int. Ed. 2009, 48, 5526-5529.

[12] A. Doddi, C. Gemel, M. Winter, R. A Fischer, C. Goedecke, H. S. Rzepa G. Frenking, Angew. Chem. 2013, 125, 468-472; Angew. Chem. Int. Ed. 2013, 52, 450-454.

[13] C. Ganesamoorthy, D. Bläser, C. Wölper, S. Schulz, Chem. Commun. 2014, 50, 12382-12384.

[14] a) L. Tuscher, C. Ganesamoorthy, D. Bläser, C. Wölper, S. Schulz, Angew. Chem. 2015, 127, 10803-10807; Angew. Chem. Int. Ed. 2015 54, 10657-10661; b) L. Tuscher, C. Helling, C. Ganesamoorthy, J. Krüger, C. Wölper, W. Frank, A. S. Nizovtsev, S. Schulz, Chem. Eur. J. 2017, 23, 12297-12304.

[15] C. Ganesamoorthy, D. Bläser, C. Wölper, S. Schulz, Angew. Chem. 2014 126, 11771-11775; Angew. Chem. Int. Ed. 2014, 53, 11587-11591.

[16] T. Chu, Y. Boyko, I. Korobkov, L. G. Kuzmina, J. A. K. Howard, G. I. Nikonov, Inorg. Chem. 2016, 55, 9099-9104.

[17] C. Ganesamoorthy, J. Krüger, C. Wölper, A. S. Nizovtsev, S. Schulz, Chem. Eur. J. 2017, 23, 2461-2468.

[18] C. Ganesamoorthy, C. Wölper, A. S. Nizovtsev, S. Schulz, Angew. Chem 2016, 128, 4276-4281; Angew. Chem. Int. Ed. 2016, 55, 4204-4209.

[19] J. K. West, L. Stahl, Inorg. Chem. 2017, 56, 12728-12738.

[20] See for instance: a) L. Weber, Chem. Rev. 1992, 92, 1839-1906; b) L. Weber, K. Reizig, D. Bungardt, R. Boese, Organometallics 1987, 6, 110 114; c) J. Grobe, D. L. van, T. Pohlmeyer, B. Krebs, O. Conrad, E. Dobbert, L. Weber, Organometallics 1998, 17, 3383-3386; d) L. Weber H. Bastian, A. Müller, H. Boegge, Z. Naturforsch. B 1992, 47, 231-237; e) L. Weber, M. Frebel, R. Boese, Organometallics 1989, 8, 1718-1722; f) W. Domańska-Babul, J. Chojnacki, E. Matern, J. Pikies, J. Organomet Chem. 2007, 692, 3640-3648.
[21] a) L. Liu, D. A. Ruiz, F. Dahcheh, G. Bertrand, R. Suter, A. M. Tondreau, H. Grützmacher, Chem. Sci. 2016, 7, 2335-2341; b) E. B. Hulley, P. T. Wolczanski, E. B. Lobkovsky, Chem. Comm. 2009, 6412-6414.

[22] a) S. Heinl, S. Reisinger, C. Schwarzmaier, M. Bodensteiner, M. Scheer Angew. Chem. 2014, 126, 7769-7773; Angw. Chem. Int. Ed. 2014, 53 7639-7642; b) E. Niecke, R. Rüger, B. Krebs, Angew. Chem. 1982, 94 553-554; Angew. Chem. Int. Ed. 1982, 21, 544-545; c) R. Riedel, H.-D. Hausen, E. Fluck, Angew. Chem. 1985, 97, 1050-1051; Angew. Chem. Int. Ed. 1985, 24, 1056-1057.

[23] Cambridge Structural Database V5.38 (update May 2017); see also: F. H. Allen, Acta Crystallogr., Sect. B: Struct. Sci. 2002, B58, 380-388. Nine hits, coordination number of As restricted to 2, any atom bonded to As, As-As bonds defined as type "double bond".

[24] P. Pyykkö, M. Atsumi, Chem. Eur. J. 2009, 15, 186-197.

[25] M. Rahm, R. Hoffmann, N. W. Ashcroft, Chem. Eur. J. 2016, 22, 1462514632.

[26] Cambridge Structural Database V5.38 (update May 2017); see also: F. H. Allen, Acta Crystallogr., Sect. B: Struct. Sci. 2002, B58, 380-388. 13 hits, coordination number of $\mathrm{Bi}$ restricted to 2 , any atom bonded to $\mathrm{Bi}, \mathrm{Bi}$ Bi bonds defined as type "double bond".

[27] A. D. Becke, Phys. Rev. A 1988, 38, 3098-3100

[28] J. P. Perdew, Phys. Rev. B 1986, 33, 8822-8824.

[29] S. Grimme, J. Antony, S. Ehrlich, H. Krieg, J. Chem. Phys. 2010, 132 154104

[30] F. Weigend. R. Ahlrichs, Phys. Chem. Chem. Phys. 2005, 7, 3297-3305.

[31] B. Metz, H. Stoll, M. Dolg, J. Chem. Phys. 2000, 113, 2563-2569.

[32] R. F. W Bader. Atoms in Molecules: A Quantum Theory, Claredon Press Oxford, U.K., 1990.

[33] A. D. Becke, K. E. Edgecombe, J. Chem. Phys. 1990, 92, 5397-5403

[34] B. Silvi, A. Savin, Nature 1994, 371, 683-686.

[35] A. E. Reed, L. A. Curtiss, F. Weinhold, Chem. Rev. 1988, 88, 899-926.

[36] A. S. Nizovtsev, A. S. Ivanov, A. I. Boldyrev, S. N. Konchenko, Eur. J. Inorg. Chem. 2015, 5801-5807.

[37] S. Raub, G. Jansen, Theor. Chem. Acc. 2001, 106, 223-232.

[38] N. J. Hardman, B. E. Eichler, P. P. Power, Chem. Commun. 2000, 1991 1992

[39] C. Cui, H. W. Roesky, H.-G. Schmidt, M. Noltemeyer, H. Hao, F Cimpoesu, Angew. Chem. 2000, 112, 4444-4446; Angew. Chem. Int. Ed. 2000, 39, 4274-4276.

[40] H. Schumann, J. Organomet. Chem. 1986, 299, 168-178.

[41] V. Vehkamäki, T. Hatanpää, M. Ritala, M. Leskelä, J. Mater. Chem. 2004 14, 3191-3197.

[42] M. Kohout, DGrid, version 4.6, Radebeul, 2011.

[43] E. van Lenthe, R. van Leeuwen, E. J. Baerends, Int. J. Quantum Chem. 1996, 57, 281-293.

[44] J.-D. Chai, M. Head-Gordon, Phys. Chem. Chem. Phys., 2008, 10, 6615-6620.

[45] M. J. Frisch, G. W. Trucks, H. B. Schlegel, G. E. Scuseria, M. A. Robb, J. R. Cheeseman, G. Scalmani, V. Barone, B. Mennucci, G. A. Petersson, H. Nakatsuji, M. Caricato, X. Li, H. P. Hratchian, A. F. Izmaylov, J. Bloino, G. Zheng, J. L. Sonnenberg, M. Hada, M. Ehara, K. Toyota, R. Fukuda, J. Hasegawa, M. Ishida, T. Nakajima, Y. Honda, O. Kitao, H. Nakai, T. Vreven, J. A. Montgomery, Jr., J. E. Peralta, F. Ogliaro, M. Bearpark, J. J. Heyd, E. Brothers, K. N. Kudin, V. N. Staroverov, R. Kobayashi, J. Normand, K. Raghavachari, A. Rendell, J. C. Burant, S. S. Iyengar, J. Tomasi, M. Cossi, N. Rega, J. M. Millam, M. Klene, J. E. Knox, J. B. Cross, V. Bakken, C. Adamo, J. Jaramillo, R. Gomperts, R. E. Stratmann, O. Yazyev, A. J. Austin, R. Cammi, C. Pomelli, J. W. Ochterski, R. L. Martin, K. Morokuma, V. G. Zakrzewski, G. A. Voth, P. Salvador, J. J. Dannenberg, S. Dapprich, A. D. Daniels, Ö. Farkas, J. B. Foresman, J. V. Ortiz, J. Cioslowski, D. J. Fox, Gaussian 09, Revision D.01; Gaussian, Inc.: Wallingford CT, 2013.

[46] ADF2013, SCM, Theoretical Chemistry, Vrije Universiteit, Amsterdam, The Netherlands, http://www.scm.com. 
[47] C. F. Guerra, J. G. Snijders, G. te Velde, E. J. Baerends, Theor. Chem Acc., 1998, 99, 391-403.

[48] G. te Velde, F. M. Bickelhaupt, E. J. Baerends, C. Fonseca Guerra, S. J. van Gisbergen, J. G. Snijders, T. Ziegler, J. Comput. Chem., 2001, 22, 931-967.

[49] G. M. Sheldrick, Acta Crystallogr. 1990, A46, 467-473

[50] G. M. Sheldrick, SHELXL-2014, Program for the Refinement of Crystal Structures University of Göttingen, Göttingen (Germany) 2014 (see also:
G. M. Sheldrick, Acta Crystallogr. 2008, A64, 112-122). shelXle, A Qt GUI for SHELXL, C. B. Hübschle, G. M. Sheldrick, B. Dittrich, J. Appl. Cryst. 2011, 44, 1281-1284.

[51] D. Kratzert, J. J. Holstein, I. Krossing, J. Appl. Cryst. 2015, 48, 933-938. 


\section{Entry for the Table of Contents}

\section{FULL PAPER}

LGa reacted with $\mathrm{PX}_{3}$ with formation of $[\mathrm{L}(\mathrm{X}) \mathrm{Ga}]_{2} \mathrm{PX}(\mathrm{X}=\mathrm{Cl} 1, \mathrm{Br}$ 2), whereas reactions with $\mathrm{AsCl}_{3}, \mathrm{Me}_{2} \mathrm{NAsCl}_{2}$, $\mathrm{As}\left(\mathrm{NMe}_{2}\right)_{3}$ and $\mathrm{Bi}\left(\mathrm{NEt}_{2}\right)_{3}$ yielded $\mathrm{Ga}$ substituted dipnictenes $\left[\mathrm{L}(\mathrm{Cl}) \mathrm{Ga}_{2} \mathrm{As}_{2}\right.$ (3), $\left[\mathrm{L}(\mathrm{Cl}) \mathrm{Ga}_{2} \mathrm{As}_{2}\left[\mathrm{Ga}\left(\mathrm{NMe}_{2}\right) \mathrm{L}\right](4)\right.$, $\left[\mathrm{L}\left(\mathrm{Me}_{2} \mathrm{~N}\right) \mathrm{Ga}_{2} \mathrm{As}_{2}(\mathbf{5})\right.$ and $\left[\mathrm{L}(\mathrm{Cl}) \mathrm{Ga}_{2} \mathrm{Bi}_{2}\right.$ (7). The stronger reductant LAl reacted with $\mathrm{As}\left(\mathrm{NMe}_{2}\right)_{3}$ under milder conditions with formation of $\left[\mathrm{L}\left(\mathrm{Me}_{2} \mathrm{~N}\right) \mathrm{Al}\right]_{2} \mathrm{As}_{2}$ (6). Quantum chemical calculations revealed the bonding situation within 4, 6 and 7 .

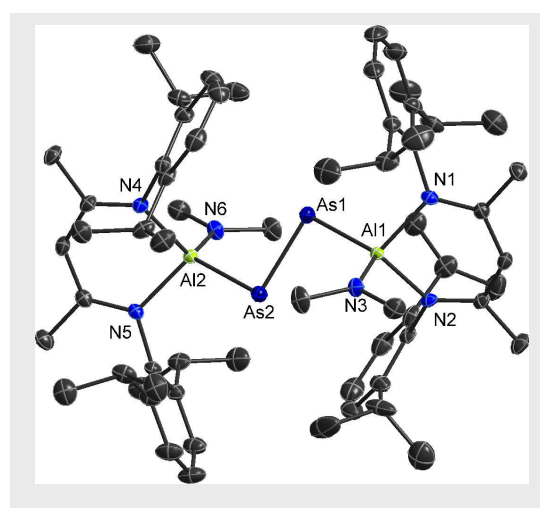

L. Tuscher, C. Helling, C. Wölper, W. Frank, A. S. Nizovtsev, and S. Schulz*

Page No. - Page No.

A general route to metal-substituted dipnictenes of the type $[L(X) M]_{2} E_{2}(M=$ $\mathrm{Al}, \mathrm{Ga}$; $\mathrm{E}=\mathrm{As}, \mathrm{Bi}$; $\mathrm{X}=$ halide, amide) 


\section{DuEPublico}

Duisburg-Essen Publications online

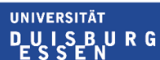

offen im Denken

Ub | universitäts

This text is made available via DuEPublico, the institutional repository of the University of Duisburg-Essen. This version may eventually differ from another version distributed by a commercial publisher.

DOI: $\quad$ 10.1002/chem.201705233

URN: urn:nbn:de:hbz:464-20201215-110613-5

This is the peer reviewed version of the following article: Tuscher, L., Helling, C., Wölper, C., Frank, W., Nizovtsev, A.S., Schulz, S.: A General Route to Metal-Substituted Dipnictenes of the Type [L(X)M]2E2. Chemistry - A European Journal 2018, 24, 3241-3250, which has been published in final form at: https://doi.org/10.1002/chem.201705233

All rights reserved. 